\title{
Review
}

\section{Interactions between endothelial cells and HIV-1}

\section{Federico Bussolino a,*, Stefania Mitola a, Guido Serini a, Giovanni Barillari b, Barbara Ensoli ${ }^{b}$}

a Department of Genetics, Biology and Biochemistry, Institute for Cancer Research and Treatment, School of Medicine, University of Torino, s.p. 142, Km. 395, 10060 Candiolo, Torino, Italy

${ }^{\mathrm{b}}$ Laboratory of Virology, Istituto Superiore di Sanità, 00100 Roma, Italy

Received 23 January 2001

\begin{abstract}
Endothelial cells (EC) participate in inflammatory and immune reactions by producing and responding to soluble mediators. Human immunodeficiency virus (HIV)-1 profoundly alters the features of EC. In some anatomical districts, they are infected by the virus and may represent a relevant reservoir. During lymphomononuclear cell diapedesis, EC activate virus replication in crossing cells. Direct or indirect damage of EC is particularly relevant in central nervous system, where blood-brain barrier perturbation is pivotal in neuronal degeneration. The observed alterations of EC adhesive properties contribute in altered leukocyte traffic from blood to lymphoid organs and tissues and play a role in the onset of immune surveillance alteration. These alterations of EC functions are relevant for the general vasculopathy, which marks the acquired immunodeficiency syndrome, and in particular are instrumental in the pathogenesis of Kaposi's sarcoma. Here we discuss the biological and molecular activation of EC in HIV-1 infection that represents the basis to understand the pathogenesis of HIV-1 associated vascular diseases. (C) 2001 Elsevier Science Ltd. All rights reserved.
\end{abstract}

Keywords: Tat; Kaposi’s sarcoma; Herpes virus 8; HIV infection; Tumors

\section{Contents}

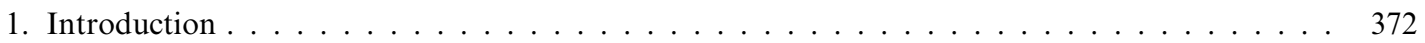

2. Restricted susceptibility of EC to HIV-1 infection . . . . . . . . . . . . . 373

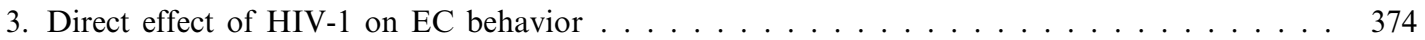

\footnotetext{
* Corresponding author. Tel.: + 39-011-9933347; fax: + 39-011-9933524.

E-mail address: fbussolino@ircc.unito.it (F. Bussolino).
} 
4. Indirect effect of HIV-1 on EC behavior: the role of Tat . . . . . . . . . . . . . . . 374

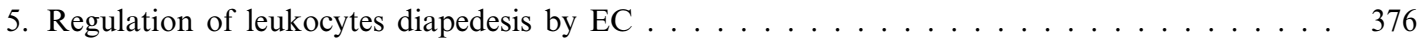

6. Kaposi's sarcoma . . . . . . . . . . . . . . . . . . . . . 376

7. The role of $\mathrm{CD}^{+}$cells and inflammatory cytokines in Kaposi's sarcoma . . . . . . . . . 378

8. The role of angiogenic inducers in Kaposi's sarcoma . . . . . . . . . . . . . . 378

9. The role of human herpes virus 8 and of HIV-1 Tat in Kaposi's sarcoma . . . . . . . . . . 379

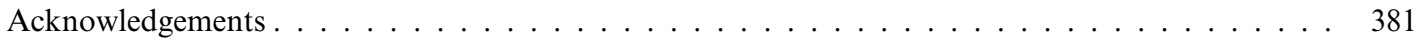

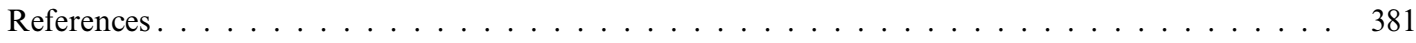

\section{Introduction}

Localized between blood and tissues, endothelium represents a dynamic barrier that regulates in-out and out-in signals resulting in the control of body homeostasis. It contributes in blood rheology by its anti-thrombotic and pro-fibrinolytic features, in delivering nutrients to and removing wastes from tissues, and in traffic of blood cells. Physical forces, alteration of soluble mediator networks or of the circulating concentration of metabolites, enzymatic defects and host invasion induce perturbations of endothelial cells (EC) and cause changes of their genetic program. Therefore, EC assume a pro-thrombotic and a pro-inflammatory phenotype and actively participate in the immune response by assuming properties of antigen presenting cells and allowing leukocytes to migrate in injured tissues or cancer cells to metastasize. In adult life, activated EC may increase their proliferative rate and generate new vessels during tissue repair, growth of solid tumors, chronic inflammatory and metabolic diseases [1,2].

Human immunodeficiency virus (HIV)-1, the etiologic agent of acquired immunodeficiency syndrome (AIDS), causes several vascular disorders characterized by an evident activation and pertur- bation of EC. These include vasculitis in several organs [3-7] but in particular in central and peripheral nervous system [8-10], serum protein leakage across the blood-brain barrier [11], thrombotic episodes [12-14], and enhanced transendothelial migration of HIV-infected monocytes in the brain that contributes to HIV-1-associated encephalitis $[15,16]$. In addition, recent evidence indicates the presence of severe morphologic alterations of the aortic endothelium in HIV-1-infected patients that are associated with EC activation and increased adhesion of mononuclear cells [17]. Finally, infected patients show a high susceptibility to manifest bacillary angiomatosis, an abnormal systemic vascular proliferation with nodule formation characterized by prominent angiogenesis and neutrophil infiltration, caused by the Gram-negative coccobacillus Bartonella henselae [18,19].

However, the most profound mark of AIDS-associated vasculopathy is Kaposi's sarcoma (KS). $\mathrm{KS}$ is the most frequent tumor of HIV-1-infected individuals, particularly homosexual men. Tumors appear multifocally and are characterized by endothelial cell activation and proliferation, as well as by inflammatory infiltrate, particularly in early stages. In progressed stages, the so-called 
KS spindle cells, which are regarded as the tumor cells of KS, dominate the histological picture [2022].

The role of EC in the pathogenesis of AIDS is not only restricted to the above mentioned pathological settings. EC from specific anatomical districts may be infected by HIV-1 and act as virus reservoir [23-26] or facilitate infection spreading in some tissues [27]. Finally, they regulate the passage of infected lymphocytes to lymphoid organs [28-30] and may contribute in metastasis dissemination of AIDS-associated lymphomas [31]. The involvement of EC in AIDS pathogenesis may be propelled by HIV-1 infection, by virus products or by infective agents responsible of opportunistic infections, that may alter EC behavior.

This review will update the most important aspects of EC interactions with HIV-1 and will emphasize the role of the activation of these cells in the pathogenesis of AIDS associated diseases, in particular of $\mathrm{KS}$.

\section{Restricted susceptibility of EC to HIV-1 infection}

Cellular entry of HIV-1 requires binding to both CD4 and to one of the seven transmembrane G-protein-coupled chemokine receptors, which act as co-receptors. HIV-1 strains have earlier been characterized by their ability to produce syncytia following infection of neoplastic cell lines (viral phenotype). Syncytium inducing viruses are frequently found in progressive or late-stage HIV disease while nonsyncytium-inducing viruses are present throughout disease. HIV-1 can also be classified by its ability to infect primary macrophages and $\mathrm{CD} 4+\mathrm{T}$ cell lines (cell tropism). All HIV-1 isolates can replicate in primary $\mathrm{T}$ cells. However, syncytium-inducing isolates that have adapted to $\mathrm{T}$ cell lines cannot replicate in macrophages, whereas some, but not all, primary non-syncytium inducing and syncytium inducing isolates can infect macrophages. This simple paradigm is complicated by the presence of dual tropic HIV-1 strains containing both syncytium inducing and non-syncytium inducing constituents capable of infecting both $\mathrm{T}$ cell lines and primary macrophages. With the discovery of the chemokine receptor family as HIV-1 entry co-receptors, HIV-1 strains can also be classified by co-receptor utilization. Strictly non-syncytium inducing ( $\mathrm{T}$ cell tropism) viruses primarily utilize $\mathrm{CC}$ receptor (R) 5, whereas strictly syncytium-inducing viruses (macrophage tropism) primarily utilize the chemokine receptor CXCR4. However, most primary syncytium inducing isolates use CXCR4 in conjunction with CCR5. Not all non syncytium-inducing isolates are capable of infecting macrophages and not all CCR5-using isolates can infect macrophages. Furthermore, some HIV1 strains can infect the cells through a CD4-independent way [32,33].

EC may be infected by lentiviruses but there are differences related to EC heterogeneity. EC from large vessel do not express CD4 molecule but may be infected by different strains of HIV-1 and HIV-2 [26,34,35] through CXCR4 [36] that is constitutively expressed on this cell type [37]. The stromal-derived factor-1 $\beta$, the ligand of CXCR4, may down-modulates its receptor and reduces the virus entry [38]. In this type of EC mature virus production is evident during the first days after infection but then declines to undetectable levels, both in the supernatants and in the cell. However, in co-culture experiments with infected EC from large vessels and CD4 positive lymphoid cells or mononuclear cells, it has been demonstrated a productive HIV-1 infection with syncytia formation of lymphoid cells [35]. This rescue activity of $\mathrm{T}$ cells and monocytes is enhanced by interferon (IFN)- $\gamma$ and by RANTES through the up-regulation of intercellular adhesion molecule-1 (ICAM1) on EC surface. This adhesion molecule seems to be pivotal in rescue mechanism, as inferred by the inhibitory role of antibodies anti-ICAM-1 in the establishment of a productive infection in the co-culture $[39,40]$. It is possible that ICAM-1 triggered by LFA-1 expressed on adhering lymphomononuclear cells elicits positive signals for virus replication. Similarly, the treatment of EC from large vessels with inflammatory cytokine [(i.e. tumor necrosis factor- $\alpha$ (TNF- $\alpha$ ) or interleukin (IL)-1] allows virus replication [41]. These data suggest that EC from large vessels are a 
reservoir of $\mathrm{HIV}-1$ that is activated when EC are perturbed.

Microvascular EC from brain, kidney glomeruli, hepatic sinusoid and bone marrow may be infected by HIV-1 and let virus replication without cytolysis $[23-26,41])$.

The infection of brain EC have been extensively studied for its relevance in neurological diseases associated to HIV-1 infection and for therapeutic implications because the central nervous system also may act as a persistent reservoir of virus since antiviral agents penetrate the blood-brain barrier poorly. T-cell tropic but not brain-derived macrophage tropic HIV strains selectively infect in vitro brain endothelium suggesting that $\mathrm{T}$-cell tropism is important for HIV entry through the blood-brain barrier [23,27] and for in vivo infection of EC in central nervous system [42-44]. A detailed analysis performed by Moses and coworkers excluded a role for CD4 and galactosylcerebroside in EC infection and may suggest the existence of strains with a specific tropism for brain EC besides those with a double specificity for $\mathrm{EC}$ and macrophages or $\mathrm{CD}$ positive cells $[23,24]$. The viral sequences responsible for $\mathrm{EC}$ infection map to a region that encompasses the $\mathrm{C} 1$ region of $e n v$ and includes overlapping reading frame for the accessory genes $v p r, v p u$, tat, and rev.

A role for the gp120 glycoprotein viral coat has also been suggested as mediator the adsorptive endocytosis of the virus in brain EC [45] by interaction with a CCR5 or CXCR4 [46]. However, it has not been exactly established the receptor used by HIV-1 to infect cerebral EC. EC have CXCR4 receptor [37] and express CCR5 at site of inflammatory injury [47] and both may sustain CD4-independent cell infection [32,48-50]. Rhesus brain EC are preferentially infected by macrophage-tropic simian immunodeficiency virus (SIV) [51,52], which uses as primary receptor CCR5 [49]. It is intriguing that circulating mononuclear cells transfer CCR5 to EC during transendothelial migration and enhance the susceptibility of EC to a productive infection during chronic inflammation [53]. Additional orphan chemokine receptors that can mediate HIV-1 or SIV cell entry could be also involved in EC infection.
The susceptibility of brain EC to a productive HIV infection may be relevant for neurological problems associated to AIDS. Through infected EC, HIV-1 may easily spread to the brain and manifests its neuropathogenicity. Alternatively the productive infection may alter features of bloodbrain barrier and thus favor the infiltration of infected cells or of HIV-1 itself [54].

\section{Direct effect of HIV-1 on EC behavior}

On the light of low and discrete susceptibility of EC to be infected by lentiviruses, there are few data on the their direct effects. Infected EC show a selective impairment in the storage and/or excretion of molecules such as endothelin-1 and Von Willebrand factor [55]. The in vitro cytotoxicity is negligible, but EC apoptosis occurs in small and medium-sized blood vessels in the brain of AIDS patients [56], an abnormality that might disrupt the blood-brain barrier [11]. It is likely that EC apoptosis may be induced by soluble stimuli released by immunocompetent and stromal cells or by viral proteins. Among them, HIV-1 gp120 is able to activate an apoptotic program in EC isolated from large vessels [46] and changes the function barrier of microvascular EC monolayer by increasing vasopermeability to middle-sized proteins [57].

\section{Indirect effect of HIV-1 on EC behavior: the role of Tat}

Tat is a transcriptional activator of viral gene expression produced early after infection and essential, for virus replication. The protein is composed of 86-104 aminoacids (according to viral isolate) encoded by two exons. In the portion encoded by the first exon (72 amino acids), four distinct regions can be recognized (N-terminal, cysteine rich, core and basic). The second exon encodes the $\mathrm{C}$-terminal region containing a $\mathrm{RGD}$ sequence [58]. During acute infection of $\mathrm{T}$ cells by HIV-1, Tat is released from the cells in an active form $[59,60]$ and via a leaderless secretory pathway that is specific and resembles that of IL-1 and 
fibroblast growth factors (FGF) [60]. In addition to its effect on paracrine and autocrine virus replication, it possesses other activities on cell functions. Tat easily enters different cell types contributing to the transactivation of HIV-1 long terminal repeat promoter in latently infected cells [61,62]. Alternatively, it acts as soluble mediator affecting physiologic functions of cells including $\mathrm{T}$ and $\mathrm{B}$ cells, monocytes, chondrocytes and neurons [63-68]. However, one of the most relevant targets for Tat is the vascular system, where it activates a pro-inflammatory and angiogenic program. Tat can up-regulate the expression of EC adhesion molecules [69,70] and induces EC to proliferate, release proteolytic enzymes [71-79]. These effects are potentiated by cell priming with inflammatory cytokines [71,72,80]. Finally, Tat induces EC adhesion to proteins of extracellular matrix and stimulates EC to undergo in vitro morphogenesis $[73,78]$. The counter part of these in vitro effects of Tat on EC is its in vivo angiogenic activity [73-76,81].

The molecular mechanisms leading to EC activation by Tat had been extensively studied. Inflammatory cytokines, and in particular IFN- $\gamma$, render EC in vitro more responsiveness to Tat by inducing the expression of $\alpha 5 \beta 1$ and $\alpha v \beta 3$ integrins $[72,78,82]$ that is a feature of activated, angiogenic EC in vivo [83]. Through its RGD sequence, Tat binds integrins [84,85] that signal inside the cells [86], and induces the phosphorylation of p125 focal adhesion kinase (B. Ensoli, unpublished data). Furthermore, inflammatory cytokines induce basic FGF expression that, in turn, induces the same integrins [80,82] and it is required for Tat-angiogenic effect [74]. The basic domain of Tat may compete with basic FGF for binding to heparin sulfate proteoglycans of the cell surface and extracellular matrix [87] and render the growth factor able to activate EC [79].

Additionally, Tat binds to and activates the tyrosine kinase receptor encoded by KDR [vascular endothelial growth factor (VEGF) receptor (R) 2] in EC and Kaposi's cells [76,81,88-91]. The natural ligands of VEGFR2 belong to the VEGF family [92] and a neutralizing antibody antiVEGFR2 or cross-desensitization between Tat and VEGF-A $\mathrm{A}_{165}$ block the activation of the recep- tor as well as the migration of EC triggered by Tat. These results are also supported by recent data showing that Tat has vasopermeabilizing effect by a direct action on EC [93,94], as demonstrated earlier for VEGF-A [92]. These effects are blocked by functional inactivation of VEGFR-2 [93].

To identify functionally important domains responsible for the activation of the angiogenic program in vascular EC, a structure-activity relationship study of Tat protein has been performed [81]. Tat binds EC with high $\left(K_{\mathrm{d}} \approx 10-30 \mathrm{pM}\right)$ and low affinity $\left(K_{\mathrm{d}} \approx 1-2 \mathrm{nM}\right)$. The basic and the cysteine-rich domain mediate the former. Tat basic domain is crucial for the binding and the activation of VEGFR-2. The relevance of the positively charged aminoacids in performing these functions is consistent with the observation that the charged residues R82, K84, H86 of VEGF-A are important for VEGFR-2 recognition [95]. Since it has been suggested that Tat forms a dimer bridging cysteine-rich regions from each monomer [61] and that two cysteine residues are pivotal for the VEGF-A dimerization and the subsequent binding to and activation of endothelium [96], it could be hypothesized that the active form of Tat on endothelium has a dimeric structure. The relevance of this domain has been also emphasized by Albini and co-workers who demonstrated its role in the migration of monocytes [97] another Tat function that requires VEGFR1 [64,98]. The Cterminus region of Tat containing RGD sequence is involved in the low affinity binding sites. $\mathrm{Mu}-$ tants in this sequence or $\mathrm{Tat}_{72}$ that lacks the product of exon 2, have reduced biological activity in vitro and in vivo, which is consistent with the earlier reports showing that integrins $\alpha \mathrm{v} \beta 3$ and $\alpha v \beta 5$ participate in Tat-induced activation of EC [72,78,79]. All together, these data suggest that regions encoded by the first exon of tat are necessary and sufficient for activation of VEGFR2. However, the C-terminal region, through RGD-mediated integrin engagement, is indispensable for a full activation of an in vitro and in vivo angiogenic program. These results are not contradictory and it is possible that Tat stimulates EC by an independent activation of integrin system and VEGFR-2 that achieve a synergy in term of 
biological functions. However, integrins and in particular $\alpha \mathrm{v} \beta 3$, show a regulatory activity on tyrosine kinase receptors $[89,99,100]$. We have recently shown that integrin $\alpha v \beta 3$ is associated to VEGF-A-stimulated VEGFR-2 and that a monoclonal antibody against $\beta 3$ integrin inhibits the activation of the receptor [89]. The blocking effects of neutralizing antibody anti- $\alpha \mathrm{v} \beta 3$ or antiVEGFR-2 [75,76,79,89] and the mapping studies performed with mutants [81] or with overlapping Tat peptides $[75,76,79]$ suggest that Tat is a unique example of molecule which turns on intracellular signals by a direct activation of both receptor and integrin systems. Furthermore, beside to have a direct role in integrin activation, the C-terminus region of Tat could regulate VEGFR2 through the presence of other determinants relevant for the engagement of neuropilin-1, a co-receptor of this tyrosine kinase receptor [101,102].

\section{Regulation of leukocytes diapedesis by EC}

The changes in soluble mediator networks characterize the early and late events of HIV-1 infection $[103,104]$ and the abnormal increased of circulating inflammatory cytokines [TNF- $\alpha$, IL-1, IL-8, monocyte chemotactic peptide (MCP) -1] renders EC more adhesive and favors the diapedesis of circulating cells [17]. Furthermore, the presence of HIV in lymphomononuclear cells, the viral proteins Tat, Nef and gp120 and the unbalance of cytokine system alter the expression of adhesion molecules (CD11a/CD18, CD49d/CD29, CD58, CD62L, CD44) on cell membrane and modify the transmigration properties of circulating cells across the vessel walls [28,70,106-111].

Furthermore, Tat also may modify the adhesion molecule profile in EC. As mentioned before, Tat induces the expression of E-selectin, up-regulates ICAM-1 and VCAM-1 in macrovascular and microvascular EC [69,70,112,113] and supports leukocyte adhesion. Furthermore, it stimulates transcription and release of IL-8 [112] and MCP-1 [93] that are powerful leukocytes chemoattractants. In vivo, the effect of Tat on leukocyte recruitment is preceded by an increased in vascular permeability, which is caused by the synthesis of platelet-activating factor in EC and may facilitate cell transmigration [93].

The role of EC in the control of leukocyte diapedesis is crucial in the development of AIDS. During transmigration, the engagement of the integrin system on infected lymphomononuclear cells and the production of inflammatory cytokines by EC result in viral replication in lymphocytes and monocytes [114,115], thus influencing the passage of HIV-1 from latency to productive replication and enhancing virus spreading. Furthermore, abnormal leukocyte traffic in is instrumental to progressive injury of lymphoid tissue and impairment of immune response. Similarly, leukocyte infiltration and abnormal cytokine response are typical features of HIV-1-associated tissue pathologies, including tumors, opportunistic infections and central nervous system degeneration [103-105,116].

\section{Kaposi's sarcoma}

$\mathrm{KS}$ is a multifocal proliferative disease of vascular origin found in four clinic-epidemiological forms. AIDS-associated KS (AIDS-KS) is the most frequent tumor of HIV-1 infected homo-bisexual men and is the most aggressive form of $\mathrm{KS}$ [21]; African KS (AKS) is frequent in certain areas of Africa, where it can represent up to $10 \%$ of the total tumors and acquires a very aggressive course after HIV-1 infection [117]; classical KS (CKS) occurs in elderly men of the Eastern-Mediterranean area and is a milder form of the disease [118]; post-transplant KS (PKS) occurs in transplanted individual after therapy with cyclosporin and corticosteroids [119]. Although these forms have a different geographical distribution and clinical course they share many common features including (i) a disturbance of the immune system characterized initially by immunoactivation particularly of CD8 T cells with Th1-type cytokine production and later, at least for AIDS-KS and PKS, by immunosuppression; (ii) histopathology of the lesions; (iii) high levels of the same inflammatory cytokines, angiogenic molecules and growth factors in the lesions; and (iv) infection by 
human herpesvirus-8 (HHV-8). These and other features of KS lesions and KS patients suggest that the different epidemiological forms of KS are mediated by the cooperation of the same cytokines and viral agents.

In vitro and in vivo experimental data and clinical observations indicate that KS may not be a true sarcoma at least in early stages but it can develop as a reactive process mediated by inflammatory cytokines and angiogenic factors whose production is triggered or enhanced by infection with HHV-8. In this context, the Tat protein of HIV-1 can increase the frequency of development and the aggressiveness of AIDS-KS. The role of cytokines, the lack of malignancy of isolated cell cultures, the lack of chromosomal alterations, the onset of $\mathrm{KS}$ as simultaneous multiple lesions in the absence of obvious metastasis and lastly, the sporadic cases of tumor regression support the hypothesis of the reactive nature of KS [120]. However, recent evidence also suggests that in later stages of development, reactive $\mathrm{KS}$ lesions may transform to a true sarcoma [121,122].

KS lesions are characterized by multiple patch, plaque or nodular lesions particularly on the skin of the extremities but often involving also the mucosae and visceral organs, particularly in AIDS-KS. The nodular stage represents a late 'tumoral' stage of the lesions and is often found at onset in AIDS-KS patients from Africa [22,123].

Histologically, early lesions are characterized by an inflammatory-granulation type reaction with activated proliferating EC, which form new blood vessels often abnormal that allow extravasation of red blood cells and edema. This can precede the appearance of the typical 'spindle cells' (KS cells) that are considered to be the tumor cells of KS. On time, the spindle cells become the predominant cell type and the lesions acquire a more monomorphic aspect resembling a fibrosarcoma, although angiogenesis remains always a prominent feature [124,125].

The nature of the inflammatory cell infiltrate of KS appears of importance since it is the first to appear and precedes the spindle cell formation. Immunohistochemical studies indicate a prevalent infiltration of $\mathrm{T}$ cells dominated by $\mathrm{CD}^{+}$cells but also containing $\mathrm{CD}^{+}{ }^{+}$cells, numerous monocyte-macrophages $\left(\mathrm{CD}^{+}, \mathrm{CD}^{+} 4^{+}, \mathrm{CD}^{+} 8^{+}\right.$, $\mathrm{CD} 45^{+}, \mathrm{PAM}-1^{+}$) often with a spindle-like morphology and a subendothelial localization, dendritic cells (FX111a1) and few B cells $\left(\mathrm{CD} 19^{+}\right.$, $\mathrm{CD}^{2} 0^{+}$or $\mathrm{CD}^{+} 0^{+}$[126-129]. In addition, the enhanced expression of adhesion molecules in resident vessels and the lack of evidence of monocytic cell proliferation in KS indicate that monocytes are recruited from the blood and differentiate in loco in macrophages and dendritic cells [130]. Therefore, KS cells produce chemokines which are able to recruit inflammatory cells [131-134]. As discussed later, these inflammatory cells, mostly $\mathrm{CD}^{+}$cells and monocytesmacrophages, produce a variety of cytokines and in particular IFN- $\gamma$, that function in a synergistic fashion to activate EC, to induce the production of angiogenic factors and a further recruitment of $\mathrm{T}$ cells and monocytes.

The nature of KS 'spindle' cells has been debated for a long time. Recent studies indicate that these cells are a heterogeneous population with three distinct phenotypes, one reminiscent of activated vascular and lymphatic EC, the other one of macrophagic and dendritic cells, the last of characterized by the presence of mixed markers of macrophage and EC [126-128,135,144].

The reactive or hyperplastic $\mathrm{KS}$ cells are not transformed nor they induce tumors in nude or SCID mice, however, they promote highly angiogenic lesions of mouse cell origin that closely resemble early human KS lesions [121,122,136138]. These lesions regress as early KS lesions can regress in humans and, as discussed below, are mediated by the angiogenic cytokines and growth factors produced by KS cells. However, although most spindle cells and, perhaps all in early stage, are reactive cells, recent evidence suggests that KS cells are 'trans-differentiated' cells and that in late stage, they may transform $[121,122,139]$.

Two transformed cell lines have been established from KS lesions that are able to give tumors in SCID but not in nude mice [121,122,140] suggesting that tumorigenic growth may require a serious host immunodeficiency. In addition, recent 
studies on nodular AIDS-KS lesions from African women indicate monoclonality of spindle cells [141]. However, due to the mixed cellularity, this type of studies cannot be performed on early lesions. On the other hand, others have also found polyclonality of the lesions [142] suggesting that tumor transformation may occur in some cases of advanced KS patients that are severely immunocompromised such as African AIDS-KS patients. Consistent with this, microsatellite instability has been observed in AIDS-KS but not in the absence of HIV-1 infection such as in CKS lesions [143].

\section{The role of $\mathrm{CD8}^{+}$cells and inflammatory cytokines in Kaposi's sarcoma}

Clinical observations suggest a role for a $\mathrm{CD} 8^{+}$ cell activation and production of inflammatory cytokines of the Th-1 type (IFN- $\gamma$ and IL-2) in KS development [22]. Recent evidence indicates that this is the case. In fact, activated peripheral blood mononuclear cells from both AIDS-KS and CKS patients produce high levels of IFN- $\gamma$ and little or no IL-4 as compared with patients without KS but with other dermatological disorders [144]. $\mathrm{CD}^{+}$cell and macrophage activation with cytokine production is also found in KS lesions from the same patients [126,144]. Thus, immunoactivation is a trait of individuals developing $\mathrm{KS}$ and production of cytokine including IFN- $\gamma$, IL-1, TNF- $\alpha$ appears to be key to KS development. In fact, the administration of IFN- $\gamma$, IL-2 or TNF- $\alpha$ to KS patients leads to disease progression or to KS development [145,146].

A variety of inflammatory cytokines is expressed in lesions from all forms of KS. These include IFN- $\gamma$, TNF- $\alpha$, IL-1, IL-6, granulocyte/ macrophages colony stimulating factor, oncostatin-M [126,144,147-149]. They are all produced by infiltrating leukocytes. This cytokine production is associated with vessel activation (ICAM-I $^{+}, \quad$ ELAM-I $^{+}, \quad$ VCAM- $^{+}, \quad$ DR $^{+}$, $\mathrm{CD} 40^{+}$, up-regulation of $\alpha 5 \beta 1$ and $\alpha v \beta 3$ integrins) $[74,126,127]$ and increased vascular adhesion of inflammatory cells [17].

Cytokines produced by activated $\mathrm{T}$ cells induce the long-term growth of cultivated KS cells,
$[150,151]$ and increase the in vivo angiogenic potential of KS cells [80]. Among them, oncostatin$M$ and IL-6, in particular, have been found to be strong KS cell growth factor [149,207,208]. However, it is clear that the effect of cytokines on KS cell growth is mediated by a synergistic stimulatory effect on production of angiogenic inducers. Besides basic FGF [74], inflammatory cytokines produced in KS lesions also induce cultured EC and $\mathrm{KS}$ cells to produce angiogenic molecules, and other cytokines and chemokines with effects on cell recruitment, growth, angiogenesis and lesion formation (discussed below). In addition, upon exposure to inflammatory cytokine EC become angiogenic in nude mice and induce formation of KS-like lesions as KS cells do [71,80]. Similarly, inoculation of inflammatory cytokines induces KS-like angiogenic lesions in mice [79], indicating that they can trigger a cascade of events leading to lesion formation.

IFN- $\gamma$ appears to be the major mediator responsible for this cascade, although IL-1 and TNF- $\alpha$ contribute in these effects in a synergistic fashion [71,80]. In addition, IFN- $\gamma$ up-regulates CD40 expression in cultured KS cells [152] and supports the progression of the lesion by its antiapoptotic and pro-angiogenic effects probably by induction of the expression of the bcl-2 protooncogene [153,154].

Altogether, these results indicate that the cytokines produced in $\mathrm{KS}$ lesions are capable of triggering a cascade of events leading to lesion formation and to maintenance and progression of KS.

\section{The role of angiogenic inducers in Kaposi's sarcoma}

The first experimental evidence that angiogenic factors are involved in KS lesion formation was provided by studies indicating the capability of $\mathrm{KS}$ cells to induce angiogenesis in the chorioallantoic membrane assay and highly angiogenic KSlike lesions after inoculation of the cells in nude mice $[138,151,74]$. These KS-like lesions are of mouse cell origin suggesting that these cells are able to recruit normal vascular cells, a phe- 
nomenon also observed in mice injected with human cells carrying $\mathrm{mT}$ oncogene of polyoma virus [156]. Lesions regress in time and are mediated by specific angiogenic factors produced by the cells. In particular, basic FGF is a key mediator of lesion formation. Inoculation of basic FGF in nude mice results in the formation of KS-like lesions [74]. In addition to its paracrine activity, basic FGF has autocrine activity in KS development because it stimulates proliferation $\mathrm{KS}$ cells [80,157]. Most importantly, both basic FGF mRNA [158] and protein [74] are highly increased in tissue sections of KS primary lesions and in KS cells. This indicates that basic FGF regulates angiogenesis and $\mathrm{KS}$ growth in humans and in urine models.

However, neutralizing anti-basic FGF antibodies or antisense oligodeoxynucleotides do not totally block lesion formation after inoculation of KS cells in mice [155] and injection of basic FGF alone does not induce the edema characteristic of KS [74]. This suggests involvement of other factors. In fact, VEGF-A, is expressed as the two secreted forms $\left(\mathrm{VEGF}-\mathrm{A}_{121}, \mathrm{VEGF}-\mathrm{A}_{165}\right)$ in both $\mathrm{KS}$ lesions and in cultured KS cells $[157,159,160]$ and its plasmatic levels are increased in patients affected by KS [161,162]. VEGF-A synergizes with basic FGF in inducing endothelial cell growth and angiogenesis as demonstrated by in vitro and mice studies $[157,159]$. VEGF-A induces the proliferation and the migration of $\mathrm{KS}$ cells $[160,163]$ though activation of VEGFR2 and involvement of $\mathrm{c}$-src and a specific adhesion focal tyrosine kinase $[164,165]$. The herpes virus HHV8 , a transmissible agent bas been postulated as the causal agent of KS (see below) and it has been recently shown that it increases the transcription of VEGF-A and VEGFR-2 [166,167]. Two other members of VEGF family, VEGF-C, which is expressed in KS lesion [168], and VEGF-D are able to activate the migration of $\mathrm{KS}$ by activating VEGFR1 and VEGFR2 [136,169].

Angiopoietins, which act through another tyrosine kinase receptor, Tie-2, are expressed in KS lesions [170] and may be important in the maturation of nascent vessel. In fact, these molecule do not show any proliferative activity but induce cells carrying the specific receptor to release molecules that recruit pericytes and smooth muscle cells around nascent vessels [171].

Another angiogenic molecule found in $\mathrm{KS}$ is hepatocyte growth factor (HGF) [90,172]. HGF induces EC to acquire spindle morphology and stimulates proliferation of cultured KS spindle cells. Moreover, HGF and its cognate receptor, the c-met protein, are expressed in human $\mathrm{KS}$ lesions, suggesting that it may play a role in $\mathrm{KS}$ development.

Platelet derived growth factor-B (PDGF) is another potent paracrine-acting mitogen for cultured KS cells that is expressed in vivo by subpopulations of cells that are intermingled with the spindle cells [173]. KS cells express PDGF $\beta$-receptor, suggesting that PDGF-B may activate the proliferation of KS cells by paracrine mechanisms. In addition, PDGF-B may have angiogenic activity suggesting that it may also contribute in the angiogenesis found in $\mathrm{KS}$ [173-177].

Platelet-activating factor is an autacoid molecule, which activates the migration of KS in autocrine manner [178,179] and has angiogenic activity [180].

Altogether these data indicate that a network of angiogenic factors and spindle cell growth factors are expressed in $\mathrm{KS}$ and regulate recruitment, survival, growth and differentiation of the different cell types, including spindle cells, present in KS lesions. The biological activities of these molecules and of the cytokines discussed above can explain the mixed cellularity and the angiogenesis of KS lesions in the context of a cytokinemediated reactive process.

\section{The role of human herpes virus 8 and of HIV-1 Tat in Kaposi's sarcoma}

Although a transmissible agent bas been postulated as the causal agent of $\mathrm{KS}$ and several viruses and other agents have been suggested [22], none has been confirmed. Recently a new herpesvirus termed human Herpesvirus 8 (HHV-8), that is closely related to Epstein-Barr-virus and herpesvirus saimiri, has been identified and shown to be present in all epidemiological forms of $\mathrm{KS}$ [181-183]. Since HHV-8 seroprevalence is low in 
areas at low incidence of $\mathrm{KS}$ and its detection can precede the onset of KS [184-186], these results suggest that HHV-8 is key to $\mathrm{KS}$ development but it requires additional factors to exert its effects in $\mathrm{KS}$ pathogenesis.

At the lesion level, HHV-8 is present in endothelial and spindle cells mostly in a latent form, [187,188] whereas mononuclear cells including monocytes-macrophages are lytically infected [189] and may support virus production and spread to other cell types.

The question whether extravasation of HHV-8 infected mononuclear cells into the tissue may be the initiating event of $\mathrm{KS}$ development or whether these cells are recruited secondarily into an early reactive focus of KS has not yet been solved. The second hypothesis, however, is supported by recent data showing that in late stage KS lesions numerous KS spindle cells express the latency associated nuclear antigen and the kaposin gene (expressed in lytic and latent infection) of HHV-8, whereas in early $\mathrm{KS}$ lesions this antigen expression is not detected, and the relative number of cells (i.e. the number of positive cells/total number of $\mathrm{KS}$ cells) expressing kaposin is much lower as compared with late stage lesions [187,188].

As other herpesviruses, HHV-8 possesses several homologs of cellular genes including cytokines (v-IL-6), chemokine receptors (v-IL-8R), chemokines (V-MIP I, II and III), viral FLICEinhibitory protein (vFLIP) and potentially transforming genes like v-bcl-2 and v-cyclin D [190-193]. However, most of these genes are expressed during lytic infection and not in latently infected KS spindle cells and only v-cyclin D and vFLIP expression can be detected by in situ hybridization in numerous $\mathrm{KS}$ spindle cells of late, but not early nodular KS lesions [194]. It is intriguing to remember that vFLIP induces a protection of virus-infected cells against deathreceptor-induced apoptosis and may lead to higher virus production and contributes to the persistence and oncogenicity of HHV-8 [195]. So, HHV-8 may be an accessory activator of KS spindle cell growth possibly mediated by vcyclin D [186] or may act indirectly by stimulat- ing the expression of cellular factors with paracrine activity.

In addition to these genes, HHV-8 encodes three chemokine ligands with interesting functional characteristics and two of them, vMIP-I and -II, can promote angiogenesis [196]. Transgenic mice expressing the HHV8-encoded viral $\mathrm{G}$ protein-coupled receptor (GPCR, a homologue of CXCR1and CXCR2) within hematopoietic cells develop angioproliferative lesions in multiple organs that morphologically resemble KS lesions. These lesions are characterized by a spectrum of changes ranging from erythematous maculae to vascular tumors, by the presence of spindle and inflammatory cells, and by expression of VEGF-A [197]. This viral protein is a constitutively signalling receptor that can bind chemokines from the CXC and the CC families, but does not require ligand for its activation [198]. It was shown that signalling by HHV-8 leads to the up-regulation of expression of VEGF-A, thereby inducing angiogenesis via a paracrine mechanism(s). In KS lesions, there is a small subset of cells expressing lytic genes that appear to be productively infected with HHV-8 [199] and GPCR is expressed by these scattered cells. Therefore, it can be argued that in KS lesions the expression of this viral receptor by a subset of infected cells could have a major contribution to HHV8-induced angiogenesis. This finding suggests that HHV8 GPCR is a critical viral gene involved in the pathogenesis of $\mathrm{KS}$, and points to the dramatic effect of paracrine stimulation of angiogenesis mediated by VEGFA secretion in $\mathrm{KS}$ pathogenesis.

On the other hand, the higher viral load found in KS patients and in late-nodular lesions suggests that individuals at risk of KS offer better conditions to virus growth and spread in the body. The same cytokine found increased in KS lesions can maintain and rescue viral growth, activate viral lytic replication and increase viral load in B cells and monocytes-macrophages [200], likely promoting HHV8 transmission to other cell types.

All factors described above including HHV-8 are present in all forms of KS. However, AIDS$\mathrm{KS}$ is more frequent and has a more aggressive 
course than the other $\mathrm{KS}$ forms, including AKS that acquires the most aggressive course after HIV-1 infection. Again, AIDS patients have at least 300-fold higher probability to get KS than individuals with primary immunodeficiency. This suggests that HIV-I itself may play a role in KS development.

The earliest evidences to support the role of Tat in AIDS-KS come from Tat transgenic mice that develop KS-like lesions [201,202]. Although Tat expression in both male and female mice was comparable, lesions developed only in male mice, mimicking the male predominance. More recently, another study supports the idea that this molecule accounts for the aggressiveness of KS in AIDS. In these animals the growth of KS cells was six fold higher than that in the non-transgenic mice [203].

In vitro studies indicate the specific role of this viral protein in activation of KS cells. Tat is capable of inducing the growth, migration, adhesion and invasion of KS cells [72-74]. KS cells express both VEGFR2 $[88,90,91,136]$ and $\alpha 5 \beta 1$ and $\alpha v \beta 3$ integrins $[78,79,82]$ that are the receptors for Tat mediating EC activation. Furthermore it promotes the synthesis by mesenchymal cells [204] of basic FGF and has synergistic activities with this growth factor in activation of $\mathrm{KS}$ cells [74].

Tat has also been shown to activate the adhesion and transmigration across capillaries of monocytes-macrophages that characterize KS lesions and contribute in production of angiogenic molecules and KS growth factors (see above) [64,67,97,109].

Extracellular Tat is detectable in AIDS-KS lesions and co-stains with these receptors on spindle cells and activated vessels, suggesting that the mechanisms described here are operative in vivo and that Tat may explain the higher frequency and aggressiveness of KS in the setting of HIV-1 infection [74].

Furthermore, the presence of detectable extracellular Tat in sera from AIDS patients [205], as well as the presence of antibodies anti-Tat in AIDS-KS patients, which recognize different epitopes as compared with those in AIDS patients [206] support the hypothesis of its role as a progression factor in AIDS-KS.

\section{Acknowledgements}

This work was supported by Italian Association for Cancer Research (AIRC), Istituto Superiore di Ministero dell' Università e della Ricerca Scientifica e Tecnologica $(60 \%$ and Programmi di Ricerca di Rilevante Interesse Nazionale-1998, 1999 and 2000), Regione Piemonte and CNR (P.F. Biotecnologie). Stefania Mitola is supported by a fellowship from Fondazione Italiana per la Ricerca sul Cancro (FIRC).

\section{References}

[1] B.D. Cines, E.S. Pollak, C.A. Buck, J.L. Loscalzo, R.P. McEver, J.S. Pober, T.M. Wick, B.A. Konkle, B.S. Schwartz, E.S. Barnathan, K.R. McCrae, B.A. Hug, A. Schmidt, D.M. Stern, Endothelial cells in physiology and in the pathophysiology of vascular disorder, Blood 91 (1998) 3527-3561.

[2] A. Mantovani, F. Bussolino, M. Introna, Cytokine regulation of endothelial cell function: from molecular level to the bedside, Immunol. Today 18 (1997) 231-239.

[3] G.M. Holland, J.S. Pepose, T.H. Pettit, M.S. Gottlieb, R.D. Yee, R.Y. Foos, Acquired immunodeficency syndrome. Ocular manifestation, Ophthalmology 90 (1983) $859-861$.

[4] J. Valeriano-Marcet, L. Ravichandran, L.D. Kerr, HIV associated systemic necrotizing vasculitis, J. Rheumatol. 17 (1990) 1091-1093.

[5] P. Tejada, B. Sarmiento, J.R. Ramos, Retinal microvasculopathy in human immunodeficiency type 1 (HIV)-infected children, Int. Ophthalmol. 21 (1997) 319-321.

[6] F.B. Smith, J.H. Arias, T.H. Elmquist, J.T. Mazzara, Microvascular cytomegalovirus endothelialitis of the lung: a possible cause of secondary pulmonary hypertension in a patient with AIDS, Chest 114 (1998) 337-340.

[7] R.J. Klaassen, R. Goldschmeding, K.M. Dolman, A.B. Vlekke, H.M. Weigel, J.K. Eeftinck Schattenkerk, J.W. Mulder, M.L. Westedt, A.E. von dem Borne, Anti-neutrophil cytoplasmic autoantibodies in patients with symptomatic HIV infection, Clin. Exp. Immunol. 87 (1992) 24-30.

[8] T.H. Brannagan III, Retroviral-associated vasculitis of the nervous system, Neurol. Clin. 15 (1997) 927-944.

[9] C.D. Katsetos, J.E. Fincke, A. Legido, H.W. Lischner, J.P. de Chadarevian, E.M. Kaye, C.D. Platsoucas, E.L. Oleszak, Angiocentric CD3(+) T-cell infiltrates in human immunodeficiency virus type 1-associated central nervous system disease in children, Clin. Diagn. Lab. Immunol. 6 (1999) 105-114.

[10] A. Vital, M. Beylot, C. Vital, B. Delors, B. Bloch, J. Julien, Morphological findings on peripheral nerve biop- 
sies in 15 patients with human immunodeficiency virus infection, Acta Neuropathol. (Berlin) 83 (1992) 618-623.

[11] C.K. Petito, K.S. Cash, Blood-brain barrier abnormalities in the acquired immunodeficiency syndrome: immunohistochemical localization of serum proteins in post-mortem brain, Ann. Neurol. 32 (1992) 658-663.

[12] D.D. Bayer, A.F. Sorbello, D.V. Condoluci, Bilateral subclavian vein thrombosis in a patient with acquired immunodeficiency syndrome, J. Am. Osteopath. Assoc. 95 (1995) 276-277.

[13] S.E. Feffer, R.L. Fox, M.M. Orsen, K.J. Harjai, A.E. Glatt, Thrombotic tendencies and correlation with clinical status in patients infected with HIV, South Med. J. 88 (1995) 1126-1130.

[14] M. Witz, J. Lehmann, Z. Korzets, Acute brachial artery thrombosis as the initial manifestation of human immunodeficiency virus infection, Am. J. Hematol. 64 (2000) 137-139.

[15] H.S. Nottet, Y. Persidsky, V.G. Sasseville, A.N. Nukuna, P. Bock, Q.H. Zhai, L.R. Sharer, R.D. McComb, S. Swindells, C. Soderland, H.E. Gendelman, Mechanisms for the transendothelial migration of HIV1-infected monocytes into brain, J. Immunol. 156 (1996) 1284-1295.

[16] Y. Persidsky, M. Stins, D. Way, M.H. Witte, M. Weinand, K.S. Kim, P. Bock, H.E. Gendelman, M. Fiala, A model for monocyte migration through the blood-brain barrier during HIV-1 encephalitis, J. Immunol. 158 (1997) 3499-3510.

[17] C. Zietz, B. Hotz, M. Sturzl, E. Rauch, R. Penning, U. Lohrs, Aortic endothelium in HIV-1 infection: chronic injury, activation, and increased leukocyte adherence, Am. J. Pathol. 149 (1996) 1887-1898.

[18] C. Dehio, Interactions of Bartonella henselae with vascular endothelial cells, Curr. Opin. Microbiol. 2 (1999) 78-82.

[19] C. Robert, C. Picard-Dahan, S. Belaich, Bacillary angiomatosis, Presse Med. 21 (1992) 1625-1630.

[20] G.J. Gottlieb, A.B. Ackerman, Kaposi's sarcoma: an extensively disseminated form in young homosexual men, Human Pathol. 13 (1981) 882.

[21] H.W. Haverkos, D.P. Drotman, Prevalence of Kaposi's sarcoma among patients with AIDS, New Engl. J. Med. 1312 (1985) 1518.

[22] B. Ensoli, M. Sturzl, Kaposi's Sarcoma: a result of the interplay among inflammatory cytokines, angiogenic factors and viral agents, Cytokine Growth Factor Rev. 9 (1998) 63-83.

[23] A. Moses, F.E. Bllom, C.D. Pauza, J.A. Nelson, Human immunodeficiency virus infection of human brain capillary endothelial cells occurs via a CD4/galactosylceramide-independent mechanism, Proc. Natl. Acad. Sci. USA 90 (1993) 10474-10478.

[24] A.S. Moses, S.G. Stenglein, J.G. Strussenberg, K. Wehrly, B. Chesebro, J.A. Nelson, Sequences regulating trophism of human immunodeficiency virus type 1 for brain capillary endothelial cells map to unique region on the viral genome, J. Virol. 70 (1996) 3401-3406.
[25] S.D. Poland, G.P. Rice, G.A. Dekaban, HIV-1 infection of human brain-derived microvascular endothelial cells in vitro, J. Acq. Immunodef. Syndr. Human Retrovirol. 8 (1995) 437-445.

[26] M.E. Lafon, J.L. Gendrault, C. Royer, D. Jaeck, A. Kirn, A.M. Steffan, Human endothelial cells isolated from the hepatic sinusoids and the umbilical vein display a different permissiveness for HIV1, Res. Virol. 144 (1993) 99-104.

[27] A.V. Moses, J.A. Nelson, HIV infection of human brain capillary endothelial cells — implications for AIDS dementia, Adv. Neuroimmunol. 4 (1994) 239-247.

[28] H.H. Birdsall, J. Trial, H.J. Lin, D.M. Green, G.W. Sorrentino, E.B. Siwak, A.L. de Jong, R.D. Rossen, Transendothelial migration of lymphocytes from HIV-1infected donors: a mechanism for extravascular dissemination of HIV-1, J. Immunol. 158 (1997) 5968-5977.

[29] R.D. Rossen, C.W. Smith, A.H. Laughter, C.A. Noonan, D.C. Anderson, W.M. McShan, M.Y. Hurvitz, F.M. Orson, HIV-1-stimulated expression of CD11/ CD18 integrins and ICAM-1: a possible mechanism for extravascular dissemination of HIV-1-infected cells, Trans. Assoc. Am. Phys. 102 (1989) 117-130.

[30] J.J. Saukkonen, S. Furfaro, K.M. Mahoney, R.M. Strieter, M. Burdick, E.A. Wright, H. Kornfeld, J.S. Berman, In vitro transendothelial migration of blood $\mathrm{T}$ lymphocytes from HIV-infected individuals, AIDS 11 (1997) 1595-1601.

[31] R. Chirivi, G. Taraboletti, M. Bani, G. Piccinini, M. Giacca, F. Bussolino, HIV-1 Tat protein promotes migration of AIDS related lymphoma cells and enhances their adhesion to endothelial cells, Blood 94 (1999) 1747-1754.

[32] J.D. Reeves, S. Hibbitts, G. Simmons, A. McKnight, J.M. Azevedo-Pereira, J. Moniz-Pereira, P.R. Clapham, Primary human immunodeficiency virus type 2 (HIV-2) isolates infect CD4-negative cells via CCR5 and CXCR4: comparison with HIV-1 and simian immunodeficiency virus and relevance to cell tropism in vivo, J. Virol. 73 (1999).

[33] N.L. Michael, Host genetic influences on HIV-1 pathogenesis, Curr. Opin. Immunol. 11 (1999) 466-474.

[34] J. Berg, B. Doe, K.S. Steimer, M. Wabl, HeLa-LAV, an epithelial cell line stably infected with HIV-1, J. Virol. Methods 34 (1991) 173-180.

[35] O. Scheglovitova, M.R. Capobianchi, G. Antonelli, D. Guanmu, F. Dianzani, CD4-positive lymphoid cells rescue HIV-1 replication form abortively infected human primary endothelial cells, Arch. Virol. 132 (1993) 267280.

[36] M. Molino, M.J. Woolkalis, N. Prevost, D. Pratico, E.S. Barnathan, G. Taraboletti, B.S. Haggarty, J. Hesselgesser, R. Horuk, J.A. Hoxie, L.F. Brass, CXCR4 on human endothelial cells can serve as both a mediator of biological responses and as a receptor for HIV-2, Biochim. Biophys. Acta 1500 (2000) 227-240. 
[37] S.K. Gupta, P.G. Lysko, K. Pillarisetti, E. Ohlstein, J.M. Stadel, Chemokine receptors in human endothelial cells. Functional expression of CXCR4 and its transcriptional regulation by inflammatory cytokines, J. Biol. Chem. 273 (1998) 4282-4287.

[38] O.O. Yang, S.L. Swanberg, Z. Lu, M. Dziejman, J. McCoy, A.D. Luster, B.D. Walker, S.H. Herrmann, Enhanced inhibition of human immunodeficiency virus type 1 by Met-stromal-derived factor 1beta correlates with down-modulation of CXCR4, J. Virol. 73 (1999) $4582-4589$.

[39] I. Abbate, F. i.F. Dianzan, G. Bianchi, F. Mosiello, F.D. Carlett, M.R. Capobianchi, RANTES stimulates cell-mediated transmission of HIV-1 infection, J. Interferon Cytokine Res. 19 (1999) 345-350.

[40] F. Dianzani, O. Scheglovitova, M. Gentile, V. Scanio, C. Barresi, B. Ficociello, F. Bianchi, D. Fiumara, M.R. Capobianchi, Interferon gamma stimulates cell-mediated transmission of HIV type 1 from abortively infected endothelial cells, AIDS Res. Human Retrovir. 12 (1996) 621-627.

[41] P.G. Conaldi, C. Serra, A. Dolei, F. Basolo, V. Falcone, G. Mariani, P. Speziale, A. Toniolo, Productive HIV-1 infection of human vascular endothelial cells requires cell proliferation and is stimulated by combined treatment with interleukin-1 beta plus tumor necrosis factoralpha, J. Med. Virol. 47 (1995) 355-363.

[42] O. Bagasra, E. Lavi, L. Bobroski, K. Khalili, J.P. Pestaner, R. Tawadros, R.J. Pomerantz, Cellular reservoirs of HIV-1 in the central nervous system of infected individuals: identification by the combination of in situ polymerase chain reaction and immunohistochemistry, AIDS 10 (1996) 573-585.

[43] S.F. An, M. Groves, B. Giometto, A.A. Beckett, F. Scaravilli, Detection and localisation of HIV-1 DNA and RNA in fixed adult AIDS brain by polymerase chain reaction/in situ hybridisation technique, Acta Neuropathol. (Berlin) 98 (1999) 481-487.

[44] L.D. Valle, S. Croul, S. Morgello, S. Amini, J. Rappaport, K. Khalili, Detection of HIV-1 Tat and JCV capsid protein, VP1, in AIDS brain with progressive multifocal leukoencephalopathy, J. Neurovirol. 6 (2000) 221-228.

[45] W.A. Banks, V. Akerstrom, A.J. Kastin, Adsorptive endocytosis mediates the passage of HIV-1 across the blood-brain barrier: evidence for a post-internalization coreceptor, J. Cell Sci. 111 (1998) 533-540.

[46] M.B. Huang, M. Hunter, V.C. Bond, Effect of extracellular human immunodeficiency virus type 1 glycoprotein 120 on primary human vascular endothelial cell cultures, AIDS Res. Human Retrovir. 15 (1999) 1265-1277.

[47] J.B. Rottman, K.P. Ganley, K. Williams, L. Wu, C.R. Mackay, D.J. Ringler, Cellular localization of the chemokine receptor CCR5. Correlation to cellular targets of HIV-1 infection, Am. J. Pathol. 151 (1997) 1341-1351.

[48] M.J. Endres, P.R. Clapham, M. Marsh, M. Ahuja, J.D. Turner, A. McKnight, J.F. Thomas, B. Stoebenau-Hag- garty, S. Choe, P.J. Vance, T.N. Wells, C.A. Power, S.S. Sutterwala, R.W. Doms, N.R. Landau, J.A. Hoxie, CD4-independent infection by HIV-2 is mediated by fusin/CXCR4, Cell 87 (1996) 745-756.

[49] A.L. Edinger, J.L. Mankowski, B.J. Doranz, B.J. Margulies, B. Lee, J. Rucker, M. Sharron, T.L. Hoffman, J.F. Berson, M.C. Zink, V.M. Hirsch, J.E. Clements, R.W. Doms, CD4-independent, CCR5-dependent infection of brain capillary endothelial cells by a neurovirulent simian immunodeficiency virus strain, Proc. Natl. Acad. Sci. USA 94 (1997) 14742-14747.

[50] A.L. Edinger, C. Blanpain, K.J. Kunstman, S.M. Wolinsky, M. Parmentier, R.W. Doms, Functional dissection of CCR5 coreceptor function through the use of CD4independent simian immunodeficiency virus strains, J. Virol. 73 (1999) 4062-4073.

[51] L.I. Strelow, D.D. Watry, H.S. Fox, J.A. Nelson, Efficient infection of brain microvascular endothelial cells by an in vivo-selected neuroinvasive SIVmac variant, J. Neurovirol. 4 (1998) 269-280.

[52] J.L. Mankowski, J.P. Spelman, H.G. Ressetar, J.D. Strandberg, J. Laterra, D.L. Carter, J.E. Clements, M.C. Zink, Neurovirulent simian immunodeficiency virus replicates productively in endothelial cells of the central nervous system in vivo and in vitro, J. Virol. 68 (1994) 8202-8208.

[53] M. Mack, A. Kleinschmidt, H. Bruhl, C. Klier, P.J. Nelson, J. Cihak, J. Plachy, M. Stangassinger, V. Erfle, D. Schlondorff, Transfer of the chemokine receptor CCR5 between cells by membrane-derived microparticles: a mechanism for cellular human immunodeficiency virus 1 infection, Nat. Med. 6 (2000) 769-775.

[54] M. Fiala, D.J. Looney, M. Stins, D.D. Way, L. Zhang, X. Gan, F. Chiappelli, E.S. Schweitzer, P. Shapshak, M. Weinand, M.C. Graves, M. Witte, K.S. Kim, TNF-alpha opens a paracellular route for HIV-1 invasion across the blood-brain barrier, Mol. Med. 3 (1997) 553-564.

[55] M.E. Lafon, A.M. Steffan, C. Royer, D. Jaeck, A. Beretz, A. Kirn, J.L. Gendrault, HIV-1 infection induces functional alterations in human liver endothelial cells in primary culture, AIDS 8 (1994) 747-752.

[56] B. Shi, U. De Girolami, J. He, S. Wang, A. Lorenzo, J. Busciglio, D. Gabuzda, Apoptosis induced by HIV-1 infection of the central nervous system, J. Clin. Invest. 98 (1996) 1979-1990.

[57] P. Annunziata, C. Cioni, E. Paccagnini, HIV-1 gp120 increases the permeability of rat brain endothelium cultures by a mechanisms involving substance P, AIDS 12 (1998) 2377-2385.

[58] K.A. Jones, M.B. Peterlin, Control of RNA initiation and elongation at the HIV-1 promoter, Annu. Rev. Biochem. 63 (1994) 717-743.

[59] B. Ensoli, L. Buonaguro, G. Barillari, V. Fiorelli, R. Gendelman, R.A. Morgan, P. Wingfield, R.C. Gallo, Release, uptake, and effects of extracellular human immunodeficiency virus type 1 Tat protein on cell growth and viral transactivation, J. Virol. 67 (1993) 277-287. 
[60] H.C. Chang, F. Samaniengo, B.C. Nair, L. Buonaguro, B. Ensoli, HIV-1 Tat protein exits from cells via a leaderless secretory pathway and binds to extracellular matrix-associated heparin sulphate proteoglycans through its basic region, AIDS 11 (1997) 1421-1431.

[61] A.D. Frankel, C.O. Pabo, Cellular uptake of the Tat protein from human immunodeficiency virus, Cell 55 (1988) 1189-1193.

[62] A. Marcuzzi, J. Wienberger, O.K. Weinberger, Transcellular activation of the human immunodeficiency virus type 1 long terminal repeat in cocultured lymphocytes, J. Virol. 66 (1992) 4228-4232.

[63] M.O. Westendorp, V.A. Shatrov, K. Schulze-Osthoff, R. Frank, M. Kraft, M. Los, P.H. Krammer, W. Droge, V. Lehmann, HIV-1 Tat potentiates TNF-induced NFkappa $\mathrm{B}$ activation and cytotoxicity by altering the cellular redox state, EMBO J. 14 (1995) 546-554.

[64] S. Mitola, S. Sozzani, W. Luini, M. Arese, A. Borstatti, H.A. Weich, F. Bussolino, Tat-HIV-1 induces human monocyte chemotaxis by activation of vascular endothelial growth factor receptor-1, Blood 90 (1997) 13651372.

[65] M.J. Orsini, C.M. Debouck, C.L. Webb, P.G. Lysko, Extracellular human immunodeficiency virus type 1 Tat protein promotes aggregation and adhesion of cerebellar neurons, J. Neurosci. 16 (1996) 2546-2552.

[66] M. Lotz, I. Clark-Lewis, V. Ganu, HIV-1 transactivator protein Tat induces proliferation and TGF beta expression in human articular chondrocytes, J. Cell Biol. 124 (1994) 365-371.

[67] R.M. Lafrenie, L.M. Wahl, J.S. Epstein, I.K. Hewlett, K.M. Yamada, S. Dhawan, HIV-1-Tat protein promotes chemotaxis and invasive behavior by monocytes, J. Immunol. 157 (1996) 974-977.

[68] L. Huang, C.J. Li, A.B. Pardee, Human immunodeficiency virus type 1 TAT protein activates B lymphocytes, Biochem. Biophys. Res. Commun. 237 (1997) 461-464.

[69] F.M. Hofman, A.D. Wright, M.M. Dohadwala, F. Wong-Staal, S.M. Walker, Exogenous tat protein activates human endothelial cells, Blood 82 (1993) 27742780 .

[70] S. Dhawan, R.K. Puri, A. Kumar, H. Duplan, J.M. Masson, B.B. Aggarwal, Human immunodeficiency virus-1-tat protein induces the cell surface expression of endothelial leukocyte adhesion molecule-1, vascular cell adhesion molecule-1, and intercellular adhesion molecule-1 in human endothelial cells, Blood 90 (1997) $1535-1544$.

[71] V. Fiorelli, R. Gendelman, F. Samaniego, P.D. Markham, B. Ensoli, Cytokines from activated T cells induce normal endothelial cells to acquire the phenotypic and functional features of AIDS-Kaposi's sarcoma spindle cells, J. Clin. Invest. 95 (1995) 1723-1734.

[72] G. Barillari, L. Buonaguro, V. Fiorelli, J. Hoffman, F. Michaels, R.C. Gallo, B. Ensoli, Effects of cytokines from activated immune cells on vascular cell growth and
HIV-1 gene expression. Implications for AIDS-Kaposi's sarcoma pathogenesis, J. Immunol. 149 (1992) 37273734.

[73] A. Albini, G. Barillari, R. Benelli, R.C. Gallo, B. Ensoli, Angiogenic properties of human immunodeficiency virus type 1 Tat protein, Proc. Natl. Acad. Sci. USA 92 (1995) 4838-4842.

[74] B. Ensoli, R. Gendelman, P. Markham, V. Fiorelli, S. Colombini, M. Raffeld, A. Cafaro, H.K. Chang, J.N. Brady, R.C. Gallo, Synergy between basic fibroblast growth factor and HIV-1 Tat protein in induction of Kaposi's sarcoma, Nature 371 (1994) 674-680.

[75] A. Albini, R. Benelli, M. Presta, M. Rusnati, M. Ziche, A. Rubartelli, G. Paglialunga, F. Bussolino, D. Noonan, HIV-tat protein is a heparin-binding angiogenic growth factor, Oncogene 12 (1996) 289-297.

[76] A. Albini, R. Soldi, D. Giunciuglio, E. Giraudo, R. Benelli, L. Primo, D. Noonan, M. Salio, G. Camussi, W. Rockl, F. Bussolino, The angiogenesis induced by HIV-1 tat protein is mediated by the Flk- $1 / \mathrm{KDR}$ receptor on vascular endothelial cells, Nat. Med. 2 (1996) 13711375.

[77] S. Dhawan, B.S. Weeks, C. Soderland, H.W. Schnaper, L.A. Toro, S.P. Asthana, I.K. Hewlett, W.G. StetlerStevenson, S.S. Yamada, K.M. Yamada, et al., HIV-1 infection alters monocyte interactions with human microvascular endothelial cells, J. Immunol. 154 (1995) $422-432$.

[78] G. Barillari, R. Gendelman, R.C. Gallo, B. Ensoli, The Tat protein of human immunodeficiency virus type 1 , a growth factor for AIDS Kaposi sarcoma and cytokineactivated vascular cells, induces adhesion of the same cell types by using integrin receptors recognizing the RGD amino acid sequence, Proc. Natl. Acad. Sci. USA 90 (1993) 7941-7945.

[79] G. Barillari, C. Sgadari, V. Fiorelli, F. Samaniego, S. Colombini, V. Manzari, A. Modesti, B.C. Nair, A. Cafaro, M. Sturzl, B. Ensoli, The Tat protein of human immunodeficiency virus type-1 promotes vascular cell growth and locomotion by engaging the $\alpha 5 \beta 1$ and $\alpha v \beta 3$ integrins and by mobilizing sequestered basic fibroblast growth factor, Blood 94 (1999) 663-672.

[80] F. Samaniego, P.D. Markham, R. Gendelman, R.C. Gallo, B. Ensoli, Inflammatory cytokines induce endothelial cells to produce and release basic fibroblast growth factor and to promote Kaposi's sarcoma-like lesions in nude mice, J. Immunol. 158 (1997) 1887-1894.

[81] S. Mitola, R. Soldi, I. Zano, L. Barra, M.I. Gutierrez, B. Berkhout, M. Giacca, F. Bussolino, Identification of specific molecular structures of human immunodeficiency virus type 1 Tat relevant for its biological effects on vascular endothelial cells, J. Virol. 74 (2000) 344353.

[82] G. Barillari, C. Sgadari, C. Palladino, R. Gendelman, A. Caputo, C.B. Morris, B.C. Nair, P. Markham, A. Nel, M. Sturzl, B. Ensoli, Inflammatory cytokines synergize with the HIV-1 Tat protein to promote angiogenesis and 
Kaposi's sarcoma via induction of basic fibroblast growth factor and the $\alpha v \beta 3$ integrin, J. Immunol. 163 (1999) 1929-1935.

[83] P.C. Brooks, R.A.F. Clark, D.A. Cheresh, Requirement of vascular integrin $\alpha \mathrm{v} \beta 3$ for angiogenesis, Science 264 (1994) 569-571.

[84] B.E. Vogel, S.J. Lee, A. Hildebrand, W. Craig, M.D. Pierschbacher, F. Wong-Staal, E. Ruoslahti, A novel integrin specificity exemplified by binding of the $\alpha v \beta 5$ integrin to the basic domain of the HIV Tat protein and vitronectin, J. Cell Biol. 121 (1993) 461-468.

[85] D.A. Brake, C. Debouck, G. Biesecker, Identification of an Arg-Gly-Asp (RGD) cell adhesion site in human immunodeficiency virus type 1 transactivation protein, tat, J. Cell Biol. 111 (1990) 1275-1281.

[86] F.G. Giancotti, E. Ruoslahti, Integrin signaling, Science 285 (1999) 1028-1032.

[87] M. Rusnati, G. Tulipano, C. Urbinati, E. Tanghetti, R. Giuliani, M. Giacca, M. Ciomei, A. Corallini, M. Presta, The basic domain in HIV-1 Tat protein as a target for polysulfonated huparin-mimicking extracellular Tat antagonists, J. Biol. Chem. 273 (1998) 16027-16037.

[88] R.K. Ganju, N. Munshi, B.C. Nair, L. Zy, P. Gill, J.E. Groopman, Human immunodeficiency virus Tat modulates the Flk-1/KDR receptor, mitogen-activated protein kinases, and components of focal adhesion in Kaposi's sarcoma cells, J. Virol. 72 (1998) 6131-6137.

[89] R. Soldi, S. Mitola, S. Strasly, P. Defilippi, G. Tarone, F. Bussolino, Role of $\alpha \mathrm{v} \beta 3$ integrin in the activation of vascular endothelial growth factor receptor-2, EMBO J. 18 (1999) 734-740.

[90] F. Montaldo, A. Maffe, M. Morini, D. Noonan, S. Giordano, A. Albini, M. Prat, Expression of functional tyrosine kinases on immortalized Kaposi's sarcoma cells, J. Cell Physiol. 184 (2000) 246-254 In process citation.

[91] M. Morini, R. Benelli, D. Giunciuglio, S. Carlone, G. Arena, D.M. Noonan, A. Albini, Kaposi's sarcoma cells of different etiologic origins respond to HIV-Tat through the flk-1/KDR (VEGFR-2): relevance in AIDSKS pathology, Biochem. Biophys. Res. Commun. 273 (2000) 267-271.

[92] F. Bussolino, A. Mantovani, G. Persico, Molecular mechanisms of blood vessel formation, Trends Biochem. Sci. 22 (1997) 251-256.

[93] M. Arese, C. Ferrandi, L. Primo, G. Camussi, F. Bussolino, HIV-1 TAT protein stimulates in vivo vascular permeability and lymphomononuclear cell recruitment, J. Immunol., in press (2000).

[94] T. Oshima, S.C. Flores, G. Vaitaitis, L.L. Coe, T. Joh, J.H. Park, Y. Zhu, B. Alexander, J.S. Alexander, HIV-1 Tat increases endothelial solute permeability through tyrosine kinase and mitogen-activated protein kinase-dependent pathways, AIDS 14 (2000) 475-482.

[95] B.A. Keyt, H.V. Nguyen, L.T. Berleau, C.M. Duarte, J. Park, H. Chen, N. Ferrara, Identification of vascular endothelial growth factor determinants for binding KDR and FLT-1 receptors. Generation of receptor-se- lective VEGF variants by site-directed mutagenesis, J. Biol. Chem. 271 (1996) 5638-5646.

[96] Y.A. Muller, B. Li, H.W. Christinger, B.C. Cunningham, A.M. de Vos, Vascular endothelial growth factor: crystal structure and functional mapping of the kinase domain receptor binding site, Proc. Natl. Acad. Sci. USA 94 (1997) 7192-7197.

[97] A. Albini, S. Ferrini, R. Benelli, S. Sforzini, D. Giunciuglio, M.G. Aluigi, A.E. Proudfoot, S. Alouani, T.N. Wells, G. Mariani, R.L. Rabin, J.M. Farber, D.M. Noonan, HIV-1 Tat protein mimicry of chemokines, Proc. Natl. Acad. Sci. USA 95 (1998) 13153-13158.

[98] L. Del Sorbo, A. Demartino, L. Biancone, B. Bussolati, P.G. Conaldi, A. Toniolo, G. Camussi, The synthesis of platelet-activating factor modulates chemotaxis of monocytes induced by HIV-1 Tat, Eur. J. Immunol. 29 (1999) 1513-1521.

[99] M. Schneller, K. Vuori, E. Ruoslahti, $\alpha v \beta 3$ integrin associates with activated insulin and PDGF $\beta$ receptors and potentiates the biological activity of PDGF, EMBO J. 16 (1997) 5600-5607.

[100] K. Vuori, E. Ruoslahti, Association of insulin receptor substrate-1 with integrins, Science 266 (1994) 15761578.

[101] S. Soker, S. Takashima, H.Q. Miao, G. Neufeld, M. Klagsbrun, Neuropilin-1 is expressed by endothelial and tumor cells as an isoform-specific receptor for vascular endothelial growth factor, Cell 92 (1998) 735-745.

[102] E. Giraudo, L. Pimo, E. Audero, H. Gerber, P. Koolwijk, S. Soker, M. Klagsbrun, N. Ferrara, F. Bussolino, Tumor necrosis factor-a regulates expression of vascular endothelial growth factor receptor-2 and of its co-receptor neuropilin-1 in human vascular endothelial cells, J. Biol. Chem. 273 (1998) 22128-22135.

[103] D. Emilie, R. Fior, L. Llorente, A. Marfaing-Koka, M. Peuchmaur, O. Devergne, B. Jarrousse, J. Wijdenes, F. Boue, P. Galanaud, Cytokines from lymphoid organs of HIV-1 infected patients: production and role in the immune disequilibrium of the disease and in the development of B lymphomas, Immunol. Rev. 140 (1994) 5-34.

[104] A.S. Fauci, Host factors and the pathogenesis of HIVinduced disease, Nature 384 (1996) 529-534.

[105] T.D. Valenzuela, D.J. Roe, G. Nichol, L.L. Clark, D.W. Spaite, R.G. Hardman, Outcomes after rapid defibrillation by security officers after cardiac arrest in casinos, New Engl. J. Med. 343 (2000) 1206-1209.

[106] P.J. Hayes, Y.M. Miao, F.M. Gotch, B.G. Gazzard, Alterations in blood leukocyte adhesion molecule rofiles in HIV-1 infection, Clin. Exp. Immunol. 117 (1999) 331-334.

[107] U. Koedel, B. Kohleisen, B. Sporer, F. Lahrtz, V. Ovod, A. Fontana, V. Erfle, H.W. Pfister, HIV type 1 Nef protein is a viral factor for leukocyte recruitment into the central nervous system, J. Immunol. 163 (1999) $1237-1245$.

[108] R.M. Lafrenie, L.M. Wahl, J.S. Epstein, I.K. Hewlett, K.M. Yamada, S. Dhawan, HIV-1-Tat modulates the 
function of monocytes and alters their interactions with microvessel endothelial cells. A mechanism of HIV pathogenesis, J. Immunol. 156 (1996) 1638-1645.

[109] J.M. Weiss, A. Nath, E.O. Major, J.W. Berman, HIV-1 Tat induces monocyte chemoattractant protein-1-mediated monocyte transmigration across a model of the human blood-brain barrier and up-regulates CCR5 expression on human monocytes, J. Immunol. 163 (1999) 2953-2959.

[110] D. Weissman, R.L. Rabin, J. Arthos, A. Rubbert, M. Dybul, R. Swofford, S. Venkatesan, J.M. Farber, A.S. Fauci, Macrophage-tropic HIV and SIV envelope proteins induce a signal through the CCR5 chemokine receptor, Nature 389 (1997) 981-985.

[111] J.M. Wang, H. Ueda, O.M. Howard, M.C. Grimm, O. Chertov, X. Gong, W. Gong, J.H. Resau, C.C. Broder, G. Evans, L.O. Arthur, F.W. Ruscetti, J.J. Oppenheim, HIV-1 envelope gp120 inhibits the monocyte response to chemokines through CD4 signal-dependent chemokine receptor down-regulation, J. Immunol. 161 (1998) 43094317.

[112] F.M. Hofman, P. Chen, F. Incardona, R. Zidovetzki, D.R. Hinton, HIV-1 tat protein induces the production of interleukin- 8 by human brain-derived endothelial cells, J. Neuroimmunol. 94 (1999) 28-39.

[113] F.M. Hofman, M.M. Dohadwala, A.D. Wright, D.R. Hinton, S.M. Walker, Exogenous tat protein activates central nervous system-derived endothelial cells, J. Neuroimmunol. 54 (1994) 19-28.

[114] M.O. Borghi, P. Panzeri, R. Shattock, S. Sozzani, A. Dobrina, P.L. Meroni, Interaction between chronically HIV-infected promonocytic cells and human umbilical vein endothelial cells: role of proinflammatory cytokines and chemokines in viral expression modulation, Clin. Exp. Immunol. 120 (2000) 93-100.

[115] S. Fan, K. Hsia, T.S. Edgington, Upregulation of human immunodeficiency virus-1 in chronically infected monocytic cell line by both contact with endothelial cells and cytokines, Blood 84 (1994) 1567-1572.

[116] O.J. Cohen, A. Kinter, A.S. Fauci, Host factors in the pathogenesis of HIV disease, Immunol. Rev. 159 (1997) $31-48$.

[117] G. Slavin, H.M. Cameron, H. Singh, Kaposi's sarcoma in mainland Tanzania: a report of 117 cases, Br. J. Cancer 23 (1969) 349-357.

[118] M. Geddes, i.M. Francesch, D. Balzi, I.S. Arnian, L. Gafà, R. Zanetti, Birthplace and classic Kaposi's sarcoma in Italy, J. Natl. Cancer Inst. 87 (1995) 1015-1017.

[119] I. Penn, Kaposi's sarcoma in organ transplant recipients: report of 20 cases, Transplantation 27 (1979) 8-11.

[120] J.J. Brooks, Kaposi's sarcoma: a reversible hyperplasia, Lancet 2 (1986) 1309-1311.

[121] Y. Lunardi-Iskandar, J.L. Bryant, R.A. Zeman, V.H. Lam, F. Samaniego, J.M. Besnier, P. Hermans, A.R. Thierry, P. Gill, R.C. Gallo, Tumorigenesis and metastasis of neoplastic Kaposi's sarcoma cell line in immunodeficient mice blocked by a human pregnancy hormone, Nature 375 (1995) 64-68.
[122] Y. Lunardi-Iskandar, P. Gill, V.H. Lam, R.A. Zeman, F. Michaels, D.L. Mann, M.S. Reitz, M. Kaplan, Z.N. Berneman, D. Carter, Isolation and characterization of an immortal neoplastyic cell line (KS Y-1) from AIDSassociated Kaposi's sarcoma, J. Natl. Cancer Inst. 87 (1995) 974-981.

[123] W.K. Roth, H. Brandstetter, M. Stürzl, Cellular and molecular features of HIV-associated Kaposi's sarcoma, AIDS 2 (1992) 895-913.

[124] Z. Ruszczak, A. Mayer-Da Silva, C.E. Orfanos, Kaposi's sarcoma in AIDS, Am. J. Dermatopathol. 9 (1987) 388-398.

[125] N.S. McNutt, V. Fletcher, M.A. Conant, Early lesions of Kaposi's sarcoma in homosexual men. An ultrastructural comparison with other vascular proliferations in skin, Am. J. Pathol. 111 (1983) 62-77.

[126] V. Fiorelli, R. Gendelman, M.C. Sirianni, H.K. Chang, S. Colombini, P.D. Markham, P. Monini, J. Sonnabend, A. Pintus, R.C. Gallo, B. Ensoli, gamma-Interferon produced by $\mathrm{CD} 8+\mathrm{T}$ cells infiltrating Kaposi's sarcoma induces spindle cells with angiogenic phenotype and synergy with human immunodeficiency virus-1 Tat protein: an immune response to human herpesvirus- 8 infection?, Blood 91 (1998) 956-967.

[127] J.A. Regezi, L.A. MacPhail, T.E. Daniels, Y.G. DeSouza, J.S. Greenspan, D. Greenspan, Human immunodeficiency virus-associated oral Kaposi's sarcoma. A heterogeneous cell population dominated by spindleshaped endothelial cells, Am. J. Pathol. 143 (1993) 240249.

[128] S. Uccini, L.P. Ruco, F. Monardo, A. Stoppacciaro, E. Dejana, I.L. La Parola, D. Cerimele, C.D. Baroni, Coexpression of endothelial cell and macrophage antigens in Kaposi's sarcoma cells, J. Pathol. 173 (1994) 23-31.

[129] B.J. Nickoloff, C.E. Griffiths, Factor XIIIa-expressing dermal dendrocytes in AIDS-associated cutaneous Kaposi's sarcomas, Science 243 (1989) 1736-1737.

[130] L.A. MacPhail, N.P. Dekker, J.A. Regezi, Macrophages and vascular adhesion molecules in oral Kaposi's sarcoma, J. Cutaneous Pathol. 23 (1996) 464-472.

[131] M.J. Endres, C.G. Garlisi, H. Xiao, L. Shan, J.A. Hedrick, The Kaposi's sarcoma-related herpesvirus (KSHV)-encoded chemokine vMIP-I is a specific agonist for the CC chemokine receptor (CCR)8, J. Exp. Med. 189 (1999) 1993-1998.

[132] S. Sozzani, W. Luini, G. Bianchi, P. Allavena, T.N. Wells, M. Napolitano, G. Bernardini, A. Vecchi, D. D’Ambrosio, D. Mazzeo, F. Sinigaglia, A. Santoni, E. Maggi, S. Romagnani, A. Mantovani, The viral chemokine macrophage inflammatory protein-II is a selective Th2 chemoattractant, Blood 92 (1998) 40364039.

[133] J.T. Stine, C. Wood, M. Hill, A. Epp, C.J. Raport, V.L. Schweickart, Y. Endo, T. Sasaki, G. Simmons, C. Boshoff, P. Clapham, Y. Chang, P. Moore, P.W. Gray, D. Chantry, KSHV-encoded CC chemokine vMIP-III is a CCR4 agonist, stimulates angiogenesis, and selectively chemoattracts TH2 cells, Blood 95 (2000) 1151-1157. 
[134] F.1. Sciacca, M. Sturzl, F. Bussolino, M. Sironi, H. Brandstetter, C. Zietz, D. Zhou, C. Matteucci, G. Peri, S. Sozzani, R. Benelli, M. Arese, A. Albini, F. Colotta, A. Mantovani, Expression of adhesion molecules, platelet-activating factor, and chemokines by Kaposi's sarcoma cells, J. Immunol. 153 (1994) 4816-4825.

[135] S. Uccini, M.C. Sirianni, L. Vincenzi, S. Topino, A. Stoppacciaro, I. Lesnoni La Parola, M. Capuano, C. Masini, D. Cerimele, M. Cella, A. Lanzavecchia, P. Allavena, A. Mantovani, C.D. Baroni, L.P. Ruco, Kaposi's sarcoma cells express the macrophage-associated antigen mannose receptor and develop in peripheral blood cultures of Kaposi's sarcoma patients, Am. J. Pathol. 150 (1997) 929-938.

[136] S. Marchio, L. Primo, M. Pagano, G. Palestro, A. Albini, T. Veikkola, I. Cascone, K. Alitalo, F. Bussolino, Vascular endothelial growth factor-C stimulates the migration and proliferation of Kaposi's sarcoma cells, J. Biol. Chem. 274 (1999) 27617-27622.

[137] B. Ensoli, S. Nakamura, S.Z. Salahuddin, P. Biberfeld, L. Larsson, B. Beaver, F. Wong-Staal, R.C. Gallo, AIDS-Kaposi's sarcoma-derived cells express cytokines with autocrine and paracrine growth effects, Science 243 (1989) 223-226.

[138] S.Z. Salahuddin, S. Nakamura, P. Biberfeld, M.H. Kaplan, P.D. Markham, L. Larsson, R.C. Gallo, Angiogenic properties of Kaposi's sarcoma-derived cells after long-term culture in vitro, Science 242 (1988) 430-433.

[139] A. Albini, I. Paglieri, G. Orengo, S. Carlone, M.G. Aluigi, R. DeMarchi, C. Matteucci, A. Mantovani, F. Carozzi, S. Donini, R. Benelli, The beta-core fragment of human chorionic gonadotrophin inhibits growth of Kaposi's sarcoma-derived cells and a new immortalized Kaposi's sarcoma cell line, AIDS 11 (1997) 713-721.

[140] B.G. Herndier, A. Werner, P. Arnstein, N.W. Abbey, F. Demartis, R.L. Cohen, M.A. Shuman, J.A. Levy, Characterization of a human Kaposi's sarcoma cell line that induces angiogenic tumors in animals, AIDS 8 (1994) $575-581$.

[141] C.S. Rabkin, S. Janz, A. Lash, A.E. Coleman, E. Musaba, L. Liotta, R.J. Biggar, Z. Zhuang, Monoclonal origin of multicentric Kaposi's sarcoma lesions, New Engl. J. Med. 336 (1997) 988-993 See comments.

[142] P. Gill, Y. Tsai, A.P. Rao, P. Jones, Clonality in Kaposi's sarcoma, New Engl. J. Med. 337 (1997) 570-571.

[143] G.C. Bedi, W.H. Westra, H. Farzadegan, P.M. Pitha, D. Sidransky, Microsatellite instability in primary neoplasms from HIV' patients, Nat. Med. 1 (1995) 65-68.

[144] M.C. Sirianni, L. Vincenzi, V. Fiorelli, S. Topino, E. Scala, S. Uccini, A. Angeloni, A. Faggioni, D. Cerimele, F. Cottoni, F. Aiuti, B. Ensoli, gamma-Interferon production in peripheral blood mononuclear cells and tumor infiltrating lymphocytes from Kaposi's sarcoma patients: correlation with the presence of human herpesvirus- 8 in peripheral blood mononuclear cells and lesional macrophages, Blood 91 (1998) 968-976.
[145] R.L. Krigel, K.A. Padavic-Shaller, A.R. Rudolph, B.J. Poiesz, R.L. Comis, Exacerbation of epidemic Kaposi's sarcoma with a combination of interleukin-2 and $\mathrm{g}$ interferon: results of a phase 2 study, J. Biol. Response Mod. 8 (1989) 359-365.

[146] D. Aboulafia, S.A. Miles, S.R. Saks, R.T. Mitsuyasu, Intravenous recombinant tumor necrosis factor in the treatment of AIDS-related Kaposi's sarcoma, J. Acq. Immundef. Syndr. 2 (1989) 54-58.

[147] J. Yang, M. Hagan, M.K. Offerman, Induction of IL-6 gene expression in Kaposi's sarcoma cells, J. Immunol. 152 (1994) 943-955.

[148] M. Sturzl, H. Brandstetter, C. Zietz, B. Eisenburg, G. Raivich, D.P. Gearin, N.H. Brockmeyer, P.H. Hofschneider, Identification of interleukin-1 and plateletderived growth factor-B as major mitogens for spindle cells of Kaposi's sarcoma: a combined in vitro and in vivo analysis, Oncogene 10 (1995) 2007-2016.

[149] S.A. Miles, A.R. Rezai, J.F. Salazar-Gonzalez, M. Vander Meyden, R.H. Stevens, D.M. Logan, R.T. Mitsuyasu, T. Taga, T. Hirano, T. Kishimoto, et al., AIDS Kaposi sarcoma-derived cells produce and respond to interleukin 6, Proc. Natl. Acad. Sci. USA 87 (1990) 4068-4072.

[150] S. Nakamura, S.Z. Salahuddin, P. Biberfeld, B. Ensoli, P.D. Markham, F. Wong-Staal, R.C. Gallo, Kaposi's sarcoma cells: long-term culture with growth factor from retrovirus-infected CD4 $+\mathrm{T}$ cells, Science 242 (1988) 426-430.

[151] B. Ensoli, S.Z. Salahuddin, R.C. Gallo, AIDS-associated Kaposi's sarcoma: a molecular model for its pathogenesis, Cancer Cells 1 (1989) 93-96.

[152] J. Pammer, A. Plettenberg, W. Weninger, B. Diller, M. Mildner, A. Uthman, W. Issing, M. Sturzl, E. Tschachler, CD40 antigen is expressed by endothelial cells and tumor cells in Kaposi's sarcoma, Am. J. Pathol. 148 (1996) 1387-1396 See comments.

[153] C.B. Morris, R. Gendelman, A.J. Marrogi, M. Lu, J.M. Lockyer, W. Alperin-Lea, B. Ensoli, Immunohistochemical detection of Bcl-2 in AIDS-associated and classical Kaposi's sarcoma, Am. J. Pathol. 148 (1996) 1055-1063.

[154] L. Biancone, V. Cantaluppi, M. Boccellino, L. Del Sorbo, S. Russo, A. Albini, I. Stamenkovic, G. Camussi, Activation of CD40 favors the growth and vascularization of Kaposi's sarcoma, J. Immunol. 163 (1999) 62016208.

[155] B. Ensoli, P. Markham, V. Kao, G. Barillari, V. Fiorelli, R. Gendelman, M. Raffeld, G. Zon, R.C. Gallo, Block of AIDS-Kaposi's sarcoma (KS) cell growth, angiogenesis, and lesion formation in nude mice by antisense oligonucleotide targeting basic fibroblast growth factor. A novel strategy for the therapy of KS, J. Clin. Invest. 94 (1994) 1736-1746.

[156] L. Primo, C. Roca, C. Ferrandi, L. Lanfrancone, F. Bussolino, Middle $\mathrm{T}$ oncogene of polyomavirus transforms human endothelial cells, Oncogene (2000), in press. 
[157] F. Samaniego, P.D. Markham, R. Gendelman, Y. Watanabe, V. Kao, K. Kowalski, J.A. Sonnabend, A. Pintus, R.C. Gallo, B. Ensoli, Vascular endothelial growth factor and basic fibroblast growth factor present in Kaposi's sarcoma (KS) are induced by inflammatory cytokines and synergize to promote vascular permeability and KS lesion development, Am. J. Pathol. 152 (1998) 1433-1443.

[158] L. Xerri, J. Hassoun, J. Planche, V. Guigou, J.J. Grob, P. Parc, D. Birnbaum, O. deLapeyriere, Fibroblast growth factor gene expression in AIDS-Kaposi's sarcoma detected by in situ hybridization, Am. J. Pathol. 138 (1991) 9-15.

[159] E. Cornali, C. Zietz, R. Benelli, W. Weninger, L. Masiello, G. Breier, E. Tschachler, A. Albini, M. Sturzl, Vascular endothelial growth factor regulates angiogenesis and vascular permeability in Kaposi's sarcoma, Am. J. Pathol. 149 (1996) 1851-1869.

[160] R. Masood, J. Cai, T. Zheng, D.L. Smith, Y. Naidu, P.S. Gill, Vascular endothelial growth factor/vascular permeability factor is an autocrine growth factor for AIDS-Kaposi sarcoma, Proc. Natl. Acad. Sci. USA 94 (1997) 979-984.

[161] P. Mercie, I. Devianne, J.F. Viallard, I. Faure, I. Pellegrin, B. Leng, M. Dupon, P. Barbeau, H. Fleury, J.L. Pellegrin, Vascular endothelial growth factor (VEGF165) plasma level increase with immunodepression in AIDS patients with Kaposi's sarcoma, Microvasc. Res. 57 (1999) 208-210.

[162] G. Ascherl, C. Hohenadl, O. Schatz, E. Shumay, J. Bogner, L. Eckhart, E. Tschachler, P. Monini, B. Ensoli, M. Sturzl, Infection with human immunodeficiency virus-1 increases expression of vascular endothelial cell growth factor in $\mathrm{T}$ cells: implications for acquired immunodeficiency syndrome-associated vasculopathy, Blood 93 (1999) 4232-4241.

[163] S. Nakamura, K. Murakami-Mori, N. Rao, H.A. Weich, B. Rajeev, Vascular endothelial growth factor is a potent angiogenic factor in AIDS-associated Kaposi's sarcomaderived spindle cells, J. Immunol. 158 (1997) 4992-5001.

[164] N. Munshi, J.E. Groopman, P.S. Gill, R.K. Ganju, c-Src mediates mitogenic signals and associates with cytoskeletal proteins upon vascular endothelial growth factor stimulation in Kaposi's sarcoma cells, J. Immunol. 164 (2000) 1169-1174.

[165] Y. Liu, R.K. Ganju, M.A. Ona, W.C. Hatch, T. Zheng, M.A. Ona, P. Gill, S. Avraham, J.E. Groopman, Cytokine signaling through the novel tysone kinase RAFTK in Kaposi's sarcoma cells, J. Clin. Invest. 99 (1997) 1798-1804.

[166] V. Fiorelli, G. Barillari, E. Toschi, C. Sgadari, P. Monini, M. Sturzl, B. Ensoli, IFN-gamma induces endothelial cells to proliferate and to invade the extracellular matrix in response to the HIV-1 Tat protein: implications for AIDS-Kaposi's sarcoma pathogenesis, J. Immunol. 162 (1999) 1165-1170.
[167] A.K. Gupta, V. Ruvolo, C. Patterson, S. Swaminathan, The human herpesvirus 8 homolog of Epstein-Barr virus $\mathrm{SM}$ protein (KS-SM) is a posttranscriptional activator of gene expression, J. Virol. 74 (2000) 1038-1044.

[168] L. Lymboussaki, T.A. Partanen, B. Olofsson, J. Thomas-Crussels, C.D. Fletcher, R.M. de Waal, A. Kaipanen, K. Alitalo, Expression of the vascular endothelial growth factor C receptor VEGFR-3 in lymphatic endothelium of the skin and in vascular tumors, Am. J. Pathol. 153 (1998) 395-403.

[169] L. Marconcini, S. Marchio, L. Morbidelli, E. Cartocci, A. Albini, M. Ziche, F. Bussolino, S. Oliviero, c-fos-induced growth factor/vascular endothelial growth factor $\mathrm{D}$ induces angiogenesis in vivo and in vitro, Proc. Natl. Acad. Sci. USA 96 (1999) 9671-9676.

[170] L.F. Brown, B.J. Dezube, K. Tognazzi, H.F. Dvorak, G.D. Yancopoulos, Expression of Tie1, Tie2, and angiopoietins 1, 2, and 4 in Kaposi's sarcoma and cutaneous angiosarcoma, Am. J. Pathol. 156 (2000) 2179-2183.

[171] D. Hanahan, Signaling vascular morphogenesis and maintenance, Science 277 (1997) 48-50.

[172] Y.M. Naidu, E.M. Rosen, R. Zitnick, I. Goldberg, M. Park, M. Naujokas, P.J. Polverini, B.J. Nickoloff, Role of scatter factor in the pathogenesis of AIDS-related Kaposi sarcoma, Proc. Natl. Acad. Sci. USA 91 (1994) 5281-5285.

[173] M. Sturzl, W.K. Roth, N.H. Brockmeyer, C. Zietz, B. Speiser, P.H. Hofschneider, Expression of plateletderived growth factor and its receptor in AIDS-related Kaposi sarcoma in vivo suggests paracrine and autocrine mechanisms of tumor maintenance, Proc. Natl. Acad. Sci. USA 89 (1992) 7046-7050.

[174] W.K. Roth, S. Werner, C.G. Schirren, P.H. Hofschneider, Depletion of PDGF from serum inhibits growth of AIDS-related and sporadic Kaposi's sarcoma cells in culture, Oncogene 4 (1989) 483-487.

[175] R. Koster, L.M. Blatt, M. Streubert, C. Zietz, H. Hermeking, W. Brysch, M. Sturzl, Consensus-interferon and platelet-derived growth factor adversely regulate proliferation and migration of Kaposi's sarcoma cells by control of c-myc expression, Am. J. Pathol. 149 (1996) 1871-1885.

[176] M. Sturzl, H. Brandstetter, C. Zietz, B. Eisenburg, G. Raivich, D.P. Gearing, N.H. Brockmeyer, P.H. Hofschneider, Identification of interleukin-1 and plateletderived growth factor-B as major mitogens for the spindle cells of Kaposi's sarcoma: a combined in vitro and in vivo analysis, Oncogene 10 (1995) 2007-2016.

[177] S. Werner, P.H. Hofschneider, C.H. Heldin, A. Ostman, W.K. Roth, Cultured Kaposi's sarcoma-derived cells express functional PDGF A-type and B-type receptors, Exp. Cell Res. 187 (1990) 98-103.

[178] L. Biancone, V. Cantaluppi, M. Boccellino, B. Bussolati, L. Del Sorbo, P.G. Conaldi, A. Albini, A. Toniolo, G. Camussi, Motility induced by human immunodeficiency virus-1 Tat on Kaposi's sarcoma cells requires plateletactivating factor synthesis, Am. J. Pathol. 155 (1999) 1731-1739. 
[179] F. Bussolino, M. Arese, G. Montrucchio, L. Barra, L. Primo, R. Benelli, F. Sanavio, M. Aglietta, D. Ghigo, M.R. Rola-Pleszczynski, et al., Platelet activating factor produced in vitro by Kaposi's sarcoma cells induces and sustains in vivo angiogenesis, J. Clin. Invest. 96 (1995) 940-952.

[180] G. Camussi, G. Montrucchio, E. Lupia, A. De Martino, L. Perona, M. Arese, A. Vercellone, A. Toniolo, F. Bussolino, Platelet-activating factor directly stimulates in vitro migration of endothelial cells and promotes in vivo angiogenesis by a heparin-dependent mechanism, J. Immunol. 154 (1995) 6492-6501.

[181] Y. Chang, E. Cesarman, M.S. Pessin, F. Lee, J. Culpepper, D.M. Knowles, P.S. Moore, Identification of herpesvirus-like DNA sequences in AIDS-associated Kaposi's sarcoma, Science 266 (1994) 1865-1869 See comments.

[182] D.H. Kedes, E. Operskalski, M. Busch, R. Kohn, J. Flood, D. Ganem, The seroepidemiology of human herpesvirus 8 (Kaposi's sarcoma-associated herpesvirus): distribution of infection in KS risk groups and evidence for sexual transmission, Nat. Med. 2 (1996) 918-924.

[183] R. Renne, W. Zhong, B. Herndier, M. McGrath, N. Abbey, D. Kedes, D. Ganem, Lytic growth of Kaposi's sarcoma-associated herpesvirus (human herpes virus 8) in culture, Nat. Med. 2 (1996) 342-346.

[184] S.J. Gao, L. Kingsley, M. Li, W. Zheng, C. Parravicini, J. Ziegler, R. Newton, C.R. Rinaldo, A. Saah, J. Phair, R. Detels, Y. Chang, P.S. Moore, KSHV antibodies among Americans, Italians and Ugandans with and without Kaposi's sarcoma, Nat. Med. 2 (1996) 925-928.

[185] G.R. Simpson, T.F. Schulz, D. Whitby, P.M. Cook, C. Boshoff, L. Rainbow, M.R. Howard, S.J. Gao, R.A. Bohenzky, P. Simmonds, C. Lee, A. de Ruiter, A. Hatzakis, R.S. Tedder, I.V. Weller, R.A. Weiss, P.S. Moore, Prevalence of Kaposi's sarcoma associated herpesvirus infection measured by antibodies to recombinant capsid protein and latent immunofluorescence antigen, Lancet 348 (1996) 1133-1138.

[186] P.S. Moore, L.A. Kingsley, S.D. Holmberg, T. Spira, P. Gupta, D.R. Hoover, J.P. Parry, L.J. Conley, H.W. Jaffe, Y. Chang, Kaposi's sarcoma-associated herpesvirus infection prior to onset of Kaposi's sarcoma, AIDS 10 (1996) 175-180.

[187] M. Sturzl, C. Blasig, A. Schreier, F. Neipel, C. Hohenadl, E. Cornali, G. Ascherl, S. Esser, N.H. Brockmeyer, M. Ekman, E.E. Kaaya, E. Tschachler, P. Biberfeld, Expression of HHV-8 latency-associated T0.7 RNA in spindle cells and endothelial cells of AIDS-associated, classical and African Kaposi's sarcoma, Int. J. Cancer 72 (1997) 68-71.

[188] L. Rainbow, G.M. Platt, G.R. Simpson, R. Sarid, S.J. Gao, H. Stoiber, C.S. Herrington, P.S. Moore, T.F. Schulz, The 222- to 234-kilodalton latent nuclear protein (LNA) of Kaposi's sarcoma-associated herpesvirus (human herpesvirus 8) is encoded by orf73 and is a component of the latency-associated nuclear antigen, J. Virol. 71 (1997) 5915-5921.
[189] C. Blasig, C. Zietz, B. Haar, F. Neipel, S. Esser, N.H. Brockmeyer, E. Tschachler, S. Colombini, B. Ensoli, M. Sturzl, Monocytes in Kaposi's sarcoma lesions are productively infected by human herpesvirus 8 , J. Virol. 71 (1997) 7963-7968.

[190] J.J. Russo, R.A. Bohenzky, M.C. Chien, J. Chen, M. Yan, D. Maddalena, J.P. Parry, D. Peruzzi, I.S. Edelman, Y. Chang, P.S. Moore, Nucleotide sequence of the Kaposi sarcoma-associated herpesvirus (HHV8), Proc. Natl. Acad. Sci. USA 93 (1996) 14862-14867.

[191] P.S. Moore, C. Boshoff, R.A. Weiss, Y. Chang, Molecular mimicry of human cytokine and cytokine response pathway genes by KSHV, Science 274 (1996) 1739-1744.

[192] F. Neipel, J.C. Albrecht, A. Ensser, Y.Q. Huang, J.J. Li, A.E. Friedman-Kien, B. Fleckenstein, Human herpesvirus 8 encodes a homolog of interleukin-6, J. Virol. 71 (1997) 839-842.

[193] R. Sarid, T. Sato, R.A. Bohenzky, J.J. Russo, Y. Chang, Kaposi's sarcoma-associated herpesvirus encodes a functional bcl-2 homologue, Nat. Med. 3 (1997) 293-298.

[194] M.A. Davis, M.A. Sturzl, C. Blasig, A. Schreier, H.G. Guo, M. Reitz, S.R. Opalenik, P.J. Browning, Expression of human herpesvirus 8-encoded cyclin D in Kaposi's sarcoma spindle cells, J. Natl. Cancer Inst. 89 (1997) 1868-1874.

[195] M. Thome, P. Schneider, K. Hofmann, H. Fickenscher, E. Meinl, F. Neipel, C. Mattmann, K. Burns, J.L. Bodmer, M. Schroter, C. Scaffidi, P.H. Krammer, M.E. Peter, J. Tschopp, Viral FLICE-inhibitory proteins (FLIPs) prevent apoptosis induced by death receptors, Nature 386 (1997) 517-521.

[196] C. Boshoff, Y. Endo, P.D. Collins, Y. Takeuchi, J.D. Reeves, V.L. Schweickart, M.A. Siani, T. Sasaki, T.J. Williams, P.W. Gray, P.S. Moore, Y. Chang, R.A. Weiss, Angiogenic and HIV-inhibitory functions of KSHV-encoded chemokines, Science 278 (1997) 290294.

[197] T.Y. Yang, S.C. Chen, M.W. Leach, D. Manfra, B. Homey, M. Wiekowski, L. Sullivan, C.H. Jenh, S.K. Narula, S.W. Chensue, S.A. Lira, Transgenic expression of the chemokine receptor encoded by human herpesvirus 8 induces an angioproliferative disease resembling Kaposi's sarcoma, J. Exp. Med. 191 (2000) 445-454.

[198] C. Bais, B. Santomasso, O. Coso, L. Arvanitakis, E.G. Raaka, J.S. Gutkind, A.S. Asch, E. Cesarman, M.C. Gershengorn, E.A. Mesri, M.C. Gerhengorn, G-proteincoupled receptor of Kaposi's sarcoma-associated herpesvirus is a viral oncogene and angiogenesis activator, Nature 391 (1998) 86-89.

[199] K.A. Staskus, W. Zhong, K. Gebhard, B. Herndier, H. Wang, R. Renne, J. Beneke, J. Pudney, D.J. Anderson, D. Ganem, A.T. Haase, Kaposi's sarcoma-associated herpesvirus gene expression in endothelial (spindle) tumor cells, J. Virol. 71 (1997) 715-719.

[200] P. Monini, S. Colombini, M. Sturzl, D. Goletti, A. Cafaro, C. Sgadari, S. Butto, M. Franco, P. Leone, S. 
Fais, G. Melucci-Vigo, C. Chiozzini, F. Carlini, G. Ascherl, E. Cornali, C. Zietz, E. Ramazzotti, F. Ensoli, M. Andreoni, P. Pezzotti, G. Rezza, R. Yarchoan, R.C. Gallo, B. Ensoli, Reactivation and persistence of human herpesvirus- 8 infection in B cells and monocytes by Th-1 cytokines increased in Kaposi's sarcoma, Blood 93 (1999) 4044-4058.

[201] A. Corallini, G. Altavilla, L. Pozzi, F. Bignozzi, M. Negrini, P. Rimessi, F. Gualandi, G. Barbanti-Brodano, Systemic expression of HIV-1 tat gene in transgenic mice induces endothelial proliferation and tumours of different histotypes, Cancer Res. 53 (1993) 5569-5575.

[202] J. Vogel, S.H. Hinrichs, K.R. Reynolds, P.A. Luciw, G. Jay, The HIV tat gene induces dermal lesions resembling Kaposi's sarcoma in transgenic mice, Nature 335 (1988) 606-611.

[203] O. Prakash, Z.Y. Tang, Y.E. He, M.S. Ali, R. Coleman, J. Gill, G. Farr, F. Samaniego, Human Kaposi's sarcoma cell-mediated tumorigenesis in human immunodeficiency type 1 tat-expressing transgenic mice, J. Natl. Cancer Inst. 92 (2000) 721-728 See comments.

[204] S.R. Opalenik, J.T. Shin, J.N. Wehby, V.K. Mahesh, J.A. Thompson, The HIV-1 TAT protein induces the expression and extracellular appearance of acidic fibroblast growth factor, J. Biol. Chem. 270 (1995) 1745717467.

[205] M.O. Westendorp, R. Frank, C. Ochsenbauer, K. Stricker, J. Dhein, H. Walczak, K.M. Debatin, P.H. Krammer, Sensitization of T cells to CD95-mediated apoptosis by HIV-1 Tat and gp120, Nature 375 (1995) 497-500.

[206] I. Demirhan, A. Chandra, F. Mueller, H. Mueller, P. Biberfeld, O. Hasselmayer, P. Chandra, Antibody spectrum against the viral transactivator protein in patients with human immunodeficiency virus type 1 infection and Kaposi's sarcoma, J. Human Virol. 3 (2000) 137-143.

[207] R. Soldi, A. Graziani, R. Benelli, D. Ghigo, A. Bosia, A. Albini, F. Bussolino, Oncostatin $\mathrm{M}$ activates phosphatidylinositol-3-kinase in Kaposi's sarcoma cells, Oncogene 9 (1994) 2253-60.

[208] B.C. Nair, A.L. de Vico, S. Nakamura, T.D. Copeland, Y. Chen, A. Potel, T. O'Neil, S. Oroszlan, R.C. Gallo, M.G. Sarngadharan, Identification of a major growth factor for AIDS - Kaposi's sarcoma cells as oncostatin M, Science 255 (1992) 1430-1432. 